OPEN ACCESS

Edited by: Carla Pinheiro,

New University of Lisbon, Portugal

Reviewed by: Jean-Philippe Marelli,

Mars, United States

Fiona Lahive,

University of Reading,

United Kingdom

*Correspondence:

Mayra Andreina Osorio Zambrano osorio.mayra@javeriana.edu.co Wilson Terán

wteran@javeriana.edu.co

Specialty section:

This article was submitted to

Plant Abiotic Stress,

a section of the journal

Frontiers in Plant Science

Received: 27 April 2021

Accepted: 16 August 2021 Published: 06 September 2021

Citation:

Osorio Zambrano MA Castillo DA, Rodríguez Pérez $L$ and Terán W (2021) Cacao (Theobroma cacao L.) Response to Water Stress:

Physiological Characterization and Antioxidant Gene Expression

Profiling in Commercial Clones.

Front. Plant Sci. 12:700855.

doi: 10.3389/fpls.2021.700855

\section{Cacao (Theobroma cacao L.) Response to Water Stress: Physiological Characterization and Antioxidant Gene Expression Profiling in Commercial Clones}

\author{
Mayra Andreina Osorio Zambrano*, Darwin Alexander Castillo, Loyla Rodríguez Pérez \\ and Wilson Terán* \\ Plant and Crop Biology, Department of Biology, Pontificia Universidad Javeriana, Bogotá, Colombia
}

The increase in events associated with drought constraints plant growth and crop performance. Cacao (Theobroma cacao L.) is sensitive to water deficit stress (DS), which limits productivity. The aim of this research was to characterise the response of seven (CCN51, FEAR5, ICS1, ICS60, ICS95, EET8, and TSH565) commercially important cacao clones to severe and temporal water deficit stress. Ten-month-old cacao trees were submitted to two treatments: well-watered and water-stressed until the leaf water potential ( $\left.\Psi_{\text {leaf }}\right)$ reached values between -3.0 and $-3.5 \mathrm{MPa}$. The effects of hydric stress on water relations, gas exchange, photochemical activity, membrane integrity and oxidative stress-related gene expression were evaluated. All clones showed decreases in $\Psi_{\text {leaf }}$, but TSH565 had a higher capacity to maintain water homeostasis in leaves. An initial response phase consisted of stomatal closure, a general mechanism to limit water loss: as a consequence, the photosynthetic rate dropped by approximately $98 \%$ on average. In some clones, the photosynthetic rate reached negative values at the maximum stress level, evidencing photorespiration and was confirmed by increased intracellular $\mathrm{CO}_{2}$. A second and photosynthetically limited phase was characterized by a drop in PSIl quantum efficiency, which affected all clones. On average, all clones were able to recover after 4 days of rewatering. Water deficit triggered oxidative stress at the early phase, as evidenced by the upregulation of oxidative stress markers and genes encoding ROS scavenging enzymes. The effects of water deficit stress on energy metabolism were deduced given the upregulation of fermentative enzyme-coding genes. Altogether, our results suggest that the EET8 clone was the highest performing under water deficit while the ICS-60 clone was more susceptible to water stress. Importantly, the activation of the antioxidant system and PSII repair mechanism seem to play key roles in the observed differences in tolerance to water deficit stress among clones.

Keywords: drought, water deficit, chlorophyll fluorescence, gas exchange, photosynthesis, oxidative stress, water potential, RT-qPCR 


\section{INTRODUCTION}

Cacao (Theobroma cacao L.) is a fruited tree native to the Amazon basin of South America (Motamayor et al., 2008; Cornejo et al., 2018), and its cultivation represents the main economic livelihood for smallholder farmers and landowners in several producing countries in Africa, Central America, and South America (Phillips-Mora et al., 2007; Baligar et al., 2008). Cacao beans are the main raw material of interest for the chocolate confectionary industry, and they are also used in the cosmetic or pharmaceutical industry, with increasing interest in recent years as a source of bioactive compounds (Prabhakaran Nair, 2010; Romero et al., 2017). Cacao bean production reached 4.6 million tons in 2017/2018 (ICCO, 2020), which benefited approximately 40 to 50 million people (Carr and Lockwood, 2011; Voora et al., 2019) and the global market is growing predicted to increase 7.3\% from 2019 to 2025 (Voora et al., 2019). However, some important threats related to global warming may reduce this growth prediction during incoming decades, such as the higher incidence of water deficit and drought periods in current cacao cultivation areas (Läderach et al., 2013; WCF (World Cocoa Foundation), 2014; Schroth et al., 2016; Medina and Laliberte, 2017; Farrell et al., 2018; Gateau-Rey et al., 2018; Lahive et al., 2019; Hebbar et al., 2020). The development and productivity of cacao trees are affected by drought (Almeida and Valle, 2007). Soil water deficit may result from a reduced water inputs to agroecosystems (Gilbert and Medina, 2016), poor irrigation, high or low temperatures, or excessive application of mineral salts and fertilizers to soil (Tardieu, 2013; Basu et al., 2016; Qaderi et al., 2019). During water deficit, the transpiration rate exceeds water absorption by the roots, thereby reducing the water content in tissues and affecting both nutrient uptake and photosynthesis (Ahuja et al., 2010; Osakabe et al., 2014; Demidchik, 2015).

To cope with water deficit periods, plants have developed several strategies and response mechanisms that vary from one plant species to another and depend on the plant phenological state or the duration and intensity of stress (Nishiyama et al., 2011; Ara et al., 2013). Some of these strategies can confer tolerance to overcome water deficit and improve recovery after rehydration (Griffiths and Parry, 2002), which is a trait of high importance for plant breeding. By 2050, half of the currently cultivated lands will likely suffer from drought (Dai, 2011; Farnese et al., 2016). This acclimation response has a genetic base and involves all different levels of plant biology, e.g., epigenetic, molecular, biochemical, and physiological, in an integrated fashion. Importantly, crosstalk between signal transduction pathways and interplay between secondary messengers have been reported as key for the effectiveness of this acclimation response at a systemic level, where abscisic acid (ABA) is considered the chief orchestrator. As water deficit stress leads to oxidative stress due to photorespiration and a concomitant increase in ROS production, deleterious oxidative damage to proteins, lipids, photosynthetic apparatus and nucleic acids accumulates in cell tissues (Noctor et al., 2002). Therefore, ROS detoxification by enzymatic and nonenzymatic systems is a crucial and well-described mechanism developed by plants against drought-induced oxidative damage (Shao et al., 2008;
Foyer and Shigeoka, 2011; Laxa et al., 2019). In addition, high activity levels of antioxidant enzymes, such as superoxide dismutase (SOD), NADPH oxidases (RBOH), glutathione S-transferase (GST), and alcohol dehydrogenase (ADH), have been shown to contribute to the attenuation of oxidative stress caused by water scarcity (Mittler, 2002; Ahuja et al., 2010) and can be used as indicators of tolerance or susceptibility to this abiotic stress (Saleh and Plieth, 2009).

The above effects of drought on plant fitness, as well as the different levels of response and mechanisms developed by plants, have been widely studied in the model plant Arabidopsis thaliana and in crops of world economic importance, such as rice (Oryza sativa L.) or maize (Zea mays L.) (Jackson et al., 2009; Akhtar and Nazir, 2013; Nakashima et al., 2014). However, this is not the case for many tropical crops of commercial importance, such as cacao. Few studies have addressed the important physiological effects of water deficit in cacao, which leads to abscission of vegetative and reproductive organs, a reduction in photosynthesis, water use efficiency and dry matter accumulation, and decreases cacao beans production yields by 10 to $89 \%$ (Zuidema et al., 2005; Köhler et al., 2010; Moser et al., 2010; Schwendenmann et al., 2010; Gateau-Rey et al., 2018). However, additional efforts are needed to increase our understanding of the different mechanisms supporting the cacao acclimation response to water deficit and its variability among genotypes (Ahuja et al., 2010; Osakabe et al., 2014; Farnese et al., 2016; Mosa et al., 2017). With this focus, we assessed the effect of a period of water deficit and recovery on the physiological response and behavior of seven cacao clones of commercial importance. Further expression profiling of genes involved in the oxidative response and soil water deficit was carried out on three clones representative of the different responses found.

\section{MATERIALS AND METHODS}

\section{Plant Material and Stress Treatment}

This study was carried out at Bambusa Station (Geoambiente SAS), which is located in the dry premontane forest at $5^{\circ} 07^{\prime} 50^{\prime \prime}$ north and $74^{\circ} 09^{\prime} 30^{\prime \prime}$ west and 1,304 m.a.s.l. in Pacho (Cundinamarca-Colombia). All clones were propagated in a glasshouse by grafting and using Caucasia (Colombian) rootstock (Geoambiente SAS) for mass production. Ten-monthold well-developed seedlings were used for the experiment. The commercial clones EET8, FEAR5, CCN51, TSH565, ICS1, ICS60, and ICS95 were selected because they belong to the group of the most recommended materials for planting and marketing in Colombia by the National Cacao Council (Cardona, 2010) and based on their agronomic performance (Table 1).

For the establishment of the experiment in the glasshouse, the seedlings were planted in black plastic bags that contained $5 \mathrm{~kg}$ (10 L) of silty loam soil ( $\mathrm{pH}$ 6.5). Considering the results of the soil analysis, each plant was fertilized with $5 \mathrm{~mL}$ of Agroplus $^{\circledR}$ (Fundases) and 5 g of 15-15-15 (N-P-K) Nutrimon ${ }^{\circledR}$ (Monómeros Colombo Venezolanos S.A) per liter of water. This fertilization scheme was applied twice after grafting to ensure the mineral requirements of the plants for optimal growth and 
TABLE 1 | Cacao commercial clones used in this study.

\begin{tabular}{|c|c|c|c|c|c|}
\hline $\begin{array}{l}\text { Genotype } \\
\text { (Nomenclature) }\end{array}$ & Identity & Genetic group & Origin & Agronomic traits & References \\
\hline CNN51 & Castro Naranjal Collection & $\begin{array}{l}\text { Amazonian- Trinitarian } \\
\text { Hybrid }\end{array}$ & Ecuador & $\begin{array}{l}\text { High Productivity, early } \\
\text { fructification, and diseases } \\
\text { resistant }\end{array}$ & $\begin{array}{l}\text { Boza et al., 2014; García } \\
\text { Lozano, 2014; Perea } \\
\text { Villamil et al., } 2017\end{array}$ \\
\hline EET8 & $\begin{array}{l}\text { Tropical Experimental } \\
\text { Station }\end{array}$ & Amazonian type-Trinitarian & Ecuador & High bean index & $\begin{array}{l}\text { Joly and Hahn, 1989; } \\
\text { Perea Villamil et al., } 2017\end{array}$ \\
\hline FEAR5 & $\begin{array}{l}\text { Fedecacao Arauquita } 5 \text { RC } \\
\text { ICA } 4179\end{array}$ & Trinitarian Hybrid & $\begin{array}{l}\text { Arauquita (Arauca } \\
\text { Colombia) }\end{array}$ & High quality and yield & Perea Villamil et al., 2017 \\
\hline ICS1 & Imperial College Selection & Trinitarian Hybrid & $\begin{array}{l}\text { Trinidad, Nicaragua, and } \\
\text { Venezuela }\end{array}$ & High bean and pod index & $\begin{array}{l}\text { Johnson et al., 2009; Perea } \\
\text { Villamil et al., } 2017\end{array}$ \\
\hline ICS60 & Imperial College Selection & Trinitarian Hybrid & $\begin{array}{l}\text { Trinidad, Nicaragua, and } \\
\text { Venezuela }\end{array}$ & $\begin{array}{l}\text { High bean and pod index, } \\
\text { medium tolerance to } \\
\text { moniliasis and witch broom } \\
\text { diseases }\end{array}$ & $\begin{array}{l}\text { Bekele et al., 2006; } \\
\text { Johnson et al., 2009; } \\
\text { García Lozano, 2014; } \\
\text { Perea Villamil et al., } 2017\end{array}$ \\
\hline ICS95 & Imperial College Selection & Trinitarian Hybrid & $\begin{array}{l}\text { Trinidad, Nicaragua, and } \\
\text { Venezuela }\end{array}$ & $\begin{array}{l}\text { High bean and pod index, } \\
\text { medium tolerance to } \\
\text { moniliasis and witch broom } \\
\text { diseases }\end{array}$ & $\begin{array}{l}\text { Bekele et al., 2006; } \\
\text { Johnson et al., 2009; } \\
\text { García Lozano, 2014; } \\
\text { García Lozano and Moreno } \\
\text { Fonseca, 2016; Perea } \\
\text { Villamil et al., } 2017\end{array}$ \\
\hline TSH565 & Trinidad Selection Hybrid & Trinitarian & Trinidad & $\begin{array}{l}\text { High production and } \\
\text { moniliasis resistance }\end{array}$ & $\begin{array}{l}\text { Johnson et al., 2009; Perea } \\
\text { Villamil et al., } 2017\end{array}$ \\
\hline
\end{tabular}

development. From the time of sowing to the application of water stress treatment, all plants were irrigated to field capacity. During the evaluation period, the maximum and minimum temperatures and relative humidity were registered daily with a HOBO 8 weather station (HBOware ${ }^{\circledR}$ ) installed at $0.50 \mathrm{~m}$ above the ground (Supplementary Figure 1A). The mean vaporpressure deficit (VPD) (Supplementary Figure 1B) was also calculated according to the method proposed by Allen (2006) and dos Santos et al. (2013). The treatments were distributed in a split-plot arrangement under a randomized complete block design, with three replications; the two water states assessed were placed in the main plots: water deficit stress (DS) or field capacity (WW) plants, and the seven clones (Table 1) were placed in the subplots. For the WW treatment, seedlings were well watered to maintain an optimal soil volumetric water content (VWC) of 45\% during the evaluation period (Figure 1A). Consequently, the VWC was registered manually at $20 \mathrm{~cm}$ depth in the soil of each plant using a FieldScout TDR-300 Moisture Meter (Spectrum Technologies ${ }^{\circledR}$ ). Under field capacity, the predawn foliar water potential $\left(\Psi_{\text {leaf }}\right)$ remained between -0.2 and $-0.4 \mathrm{MPa}$ according to a previously reported $\Psi_{\text {leaf }}$ value for well-irrigated cacao plants (Figure 1B; De Almeida et al., 2016). In the DS treatment, irrigation was suspended for 26 consecutive days until $\Psi_{\text {leaf }}$ reached values between -3.0 and -3.5 MPa (Rada et al., 2005; dos Santos et al., 2014) moment in which the VWC reached 6\% (Figures 1A,B), and the plants showed critical wilting (e.g., leaf senescence and floral bud abortion). According to the $\Psi_{\text {leaf }}$ and VWC, day 26 after treatment (D26) was established as the maximum water deficit stress point (Almeida et al., 2002; García Lozano and Moreno Fonseca, 2016). At the end of D26, all plants were irrigated to field capacity for recovery, reaching $45 \%$ of the VWC the day after. Recovery measurements were realized during the following 4 days after rehydration (DAR).

\section{Physiological Parameters Measurements Leaf Water Potential}

The $\Psi_{\text {leaf }}$ value was measured pre-dawn from 5:00 to 6:30 am in 3 or 4 completely expanded leaves from the top to the bottom of six plants per treatment $(n=6)$ and for each clone (Figure 1B), and it was measured with a Schölander pressure chamber (PMS Model 615, Fresno, CA, United States).

\section{Gas Exchange and Intrinsic Water Use Efficiency}

The parameters net photosynthesis (A), stomatic conductance $\left(\mathrm{g}_{s}\right)$ and intercellular $\mathrm{CO}_{2}\left(\mathrm{C}_{i}\right)$ were registered from 9:00 am to $12 \mathrm{~m}$ in 3 or 4 completely expanded leaves from top to bottom of nine plants per treatment $(n=9)$ and per clone using a LI-6400XT Portable Photosynthesis System measurement system (LI-COR Biosciences Inc. NE, United States) with an ambient $\mathrm{CO}_{2}$ concentration $\left(\mathrm{C}_{a}\right)$ of $400 \mu$ moles $\mathrm{m}^{-2} \mathrm{~s}^{-1}$ (De Almeida et al., 2016) and a photosynthetic photon flux density (PFD) of $500 \mu$ moles $\mathrm{m}^{-2} \mathrm{~s}^{-1}$ according to the response of photosynthesis to light for each clone (data not shown). The intrinsic water use efficiency $\left(\mathrm{WUE}_{i}\right)$ was calculated with $\mathrm{A}$ and $\mathrm{g}_{s}$ data $\left(\mathrm{A} / \mathrm{g}_{s}\right)$.

\section{Chlorophyll Fluorescence Parameters}

The maximum quantum yield of PSII $\left(\mathrm{F}_{v} / \mathrm{F}_{m}\right)$ was measured in dark-adapted leaves for 45 minutes and the effective quantum yield of PSII (Y[II]) was measured during a repetitive saturating actinic light pulse equivalent to the ambient light (Tounekti et al., 2018), on the same leaves where photosynthesis was recorded $(n=9)$. For this, the chlorophyll molecules were excited for $0.80 \mathrm{~s}$ with 1,500 $\mu$ moles $\mathrm{m}^{-2} \mathrm{~s}^{-1}$ actinic light. Measurements were realized from 4:00 to 7:00 pm, using a Junior-PAM modulated fluorometer (Walz ${ }^{\circledR}$, Effeltrich, Germany) and the parameters were calculated with WinControl-3 software 

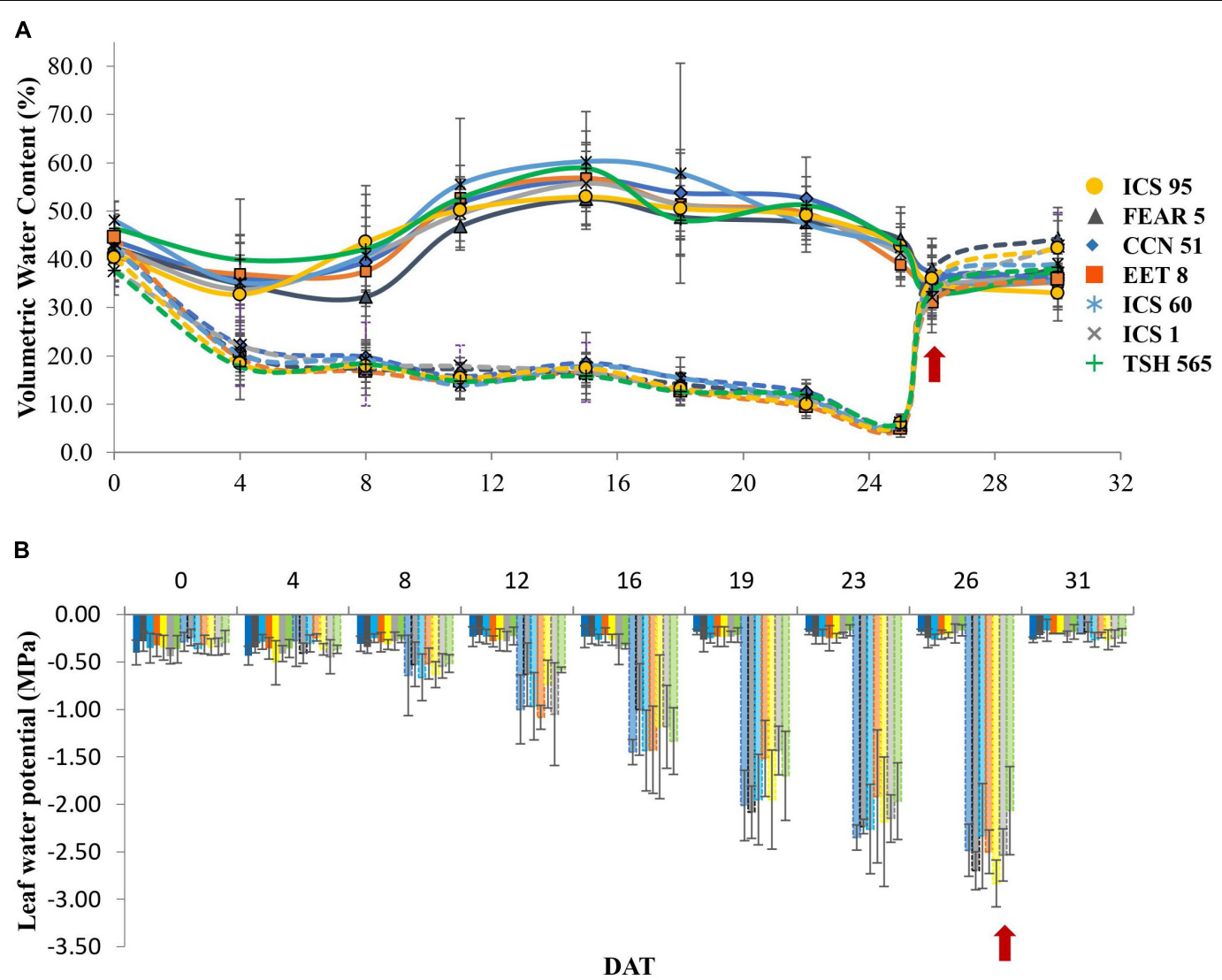

$\begin{array}{lllllll}\text { —CCN51-WW } & \text { 口EAR 5-WW } & \text { ICS 60-WW } & \text { EET8-WW } & \text { ICS95-WW } & \text { ICS1-WW } & \text { TSH565-WW } \\ \text { DCCN51-DS } & \text { J FEAR 5-DS } & \text { ICS 60-DS } & \text { EET8-DS } & \text { ICS95-DS } & \text { ICS1-DS } & \text { TSH565-DS }\end{array}$

FIGURE 1 | Variation in the (A) soil volumetric water content and (B) predawn water potential of cacao clones under different water states. WW, well-watered (solid lines); DS, water deficit (dashed lines) conditions. Values are the mean $\pm \operatorname{SD}(n=6)$. The arrows indicate the exact day of rewatering after 26 days of DS.

(Heinz Walz GmbH Inc., Effeltrich, Germany) (Issa et al., 2018; González-González et al., 2020).

\section{Relative Leaf Water Content (RWC) and Electrolyte Leakage}

The RWC leaf was determined following the protocol proposed by De Almeida et al. (2016) and according to the equation proposed by Slatyer and Shmueli (1967):

$$
\operatorname{RWC}(\%)=\left[\frac{\text { Fresh weight }- \text { dry weight }}{\text { turgid weight }- \text { dry weight }}\right] \times 100
$$

The leaf fresh weight, turgid weight and dry weight were determined in leaf pieces of $25 \mathrm{~cm}^{2}$ of 21 plants per treatment. The turgid weight was determined after hydrating the pieces with distilled water for 24 hours, and the dry weight was then recorded after drying the pieces in a $70^{\circ} \mathrm{C}$ oven to a constant weight.

The electrolyte leakage (EL) was determined using the protocol proposed by Souza et al. (2014). For this, ten 6-mmdiameter leaf discs were placed in $15 \mathrm{~mL}$ tubes with $10 \mathrm{~mL}$ of deionized water at $25^{\circ} \mathrm{C}$ under constant agitation. The electrical conductivity (EC) was determined with a conductometer (HI
9835 Hanna $^{\circledR}$ - ICT, SL, Bogota, Colombia) after 6 h of incubation and after heating the same sample at $90^{\circ} \mathrm{C}$ for $2 \mathrm{~h}$. EL was expressed as a percentage (\%) according to the equation proposed initially by Stuart (1939):

$$
\operatorname{EL}(\%)=\left[\frac{\mathrm{EC}}{\mathrm{ECmax}}\right] \times 100
$$

where, EL is the percentage of lost electrolytes, EC is the EC measured at $6 \mathrm{~h}$, and ECmax is the EC measured after heating the sample at $90^{\circ} \mathrm{C}$ for $2 \mathrm{~h}$.

\section{Gene Expression Profiling}

Among the seven clones evaluated, three clones were selected as representatives (see below) of the different responses to DS observed through the physiological variables evaluated. Samples of mature foliar tissue from three plants of each clone were taken on day 0 (control), day 23 and day 26 after DS, once physiological measurements completed (noon) and immediately frozen in liquid nitrogen for total RNA extraction. 


\section{Identification of Cacao Antioxidant System Orthologous Genes in the Cacao Genome for RT-qPCR Primer Design}

A search for genes associated with the water stress response (drought or waterlogging) and oxidative stress (antioxidant system) was performed for model plants in the literature and in sequence databases. Then, the selected CDSs (coding sequences, Table 2) from model plants were used as a query to search orthologous genes in the cacao genome hub database (Argout et al., 2017) using the reciprocal best hit strategy (Ward and Moreno-Hagelsieb, 2014) and running BLAST alignments (Altschul et al., 1990).

The best hit of each alignment was selected according to its highest alignment score and lowest E-value and after verifying its coverage length. Once confirmed as orthologs, the cacao CDS was used for qPCR primer design using Primer3Plus Software (Rozen and Skaletsky, 2000) with default parameters. Similarly, primer sequences for three housekeeping genes previously employed in RT-qPCR assays in cacao plants (Pinheiro et al., 2011) were modified to be used as normalizers of the relative expression analysis. Quality control was carried out to confirm the absence of dimer formation, Tm and primer specificity with the Sequence Manipulation Suite (Stothard, 2000) and
Primer Quest ${ }^{\circledR}$ (IDT, IA, United States). Finally, a total of nine primer pairs were designed for the respective cacao orthologous genes and three pairs were designed for the housekeeping genes (Table 2).

\section{RNA Extraction and cDNA Synthesis}

As mentioned above, all harvested leaf samples were maintained in liquid nitrogen and stored at $-80^{\circ} \mathrm{C}$ until RNA extraction. For RNA extraction, an in-house protocol was optimized based on the protocol of Chang et al. (1993), with some modifications as described in Supplementary Material. The RNA concentration and quality were assessed using a 2100 Bioanalyzer (Agilent Technologies $^{\circledR}$, CA, United States). High RNA yield $(\sim 500$ $\mathrm{ng} / \mu \mathrm{l}$ ) with an RNA integrity number (RIN) higher than 7 was obtained after optimization of the protocol. Reverse transcription was performed with $1 \mu \mathrm{g}$ of total RNA using M-MuLV Reverse Transcriptase (New England Biolabs, MA, United States) following the manufacturer's instructions and using oligo $\mathrm{d}(\mathrm{T}) 18$ primers.

\section{Relative Expression Analysis Using RT-qPCR}

The RT-qPCR relative expression analysis of each target gene was carried out in triplicate using 3 biological replicates per condition (day 0, day 23, and day 26 after DS). All amplifications

TABLE 2 | Cacao orthologous genes related to the antioxidant system evaluated in this study. The sources of selected genes, expression patterns found in previous studies and primer sequences designed for RT-qPCR analysis are detailed.

\begin{tabular}{|c|c|c|c|c|c|c|c|c|c|}
\hline Gen & Accession No. & Tc Locus name & Forward $5^{\prime}-3^{\prime}$ & Reverse $5^{\prime}-3^{\prime}$ & $\begin{array}{l}\text { Length } \\
\text { (pb) }\end{array}$ & Ta & $\begin{array}{l}\text { Observed } \\
\text { patterns }\end{array}$ & Species & Author \\
\hline SOD3.1 & AAB68035.1 & Tc10v2_t014220.1 & gtgattcttccaccgtcgtt & caatagcccaacccaaagaa & 147 & 58.5 & $\begin{array}{l}\text { Overexpression } \\
\text { during drought }\end{array}$ & $\begin{array}{l}\text { Triticum } \\
\text { aestivum }\end{array}$ & $\begin{array}{c}\text { Sheoran } \\
\text { et al., } 2015\end{array}$ \\
\hline $\mathrm{RBOHF}$ & AT1G64060.1 & Tc03_t028110 & acttgccctgtcatttggac & ccattccccactcccttatt & 136 & 58.5 & $\begin{array}{c}\text { Overexpression } \\
\text { during OS }\end{array}$ & A. thaliana & $\begin{array}{c}\text { Chaouch } \\
\text { et al., 2012; } \\
\text { Morales } \\
\text { et al., } 2016\end{array}$ \\
\hline GST & AT1G17170.1 & Tc07v2_t011790.1 & agccttactttgggggagaa & cacctcttagcccatgcaat & 142 & 57 & OS marker & A. thaliana & $\begin{array}{c}\text { Noctor } \\
\text { et al., } 2016\end{array}$ \\
\hline Hsp 17.6 & AT5G12020.1 & Tc09_t005320 & aaggagggttggcaagttct & ttcaggtggaggcagtttct & 124 & 62.5 & OS marker & A. thaliana & $\begin{array}{c}\text { Noctor } \\
\text { et al., } 2016\end{array}$ \\
\hline UGT & AT4G34131.1 & Tc02v2_t008490.1 & gggcactgaagaaaaagcag & ccccatagcgatctccatta & 160 & 58.5 & $\begin{array}{c}\text { Overexpression } \\
\text { during OS }\end{array}$ & A. thaliana & $\begin{array}{c}\text { Noctor } \\
\text { et al., } 2016\end{array}$ \\
\hline NTRC & AT2G41680.1 & Tc05_t017060 & ggttcaggtcctgctggata & ctccaggaacaccaccaact & 100 & 57 & $\begin{array}{c}\text { Overexpression } \\
\text { during OS }\end{array}$ & A. thaliana & $\begin{array}{l}\text { Kim et al., } \\
2017\end{array}$ \\
\hline$A D H$ & AT1G77120.1 & Tc08_t012590 & gtttttggactgggtgctgt & ttcgacactgcgatcaactc & 213 & 60 & $\begin{array}{l}\text { Differential } \\
\text { expression } \\
\text { during } \\
\text { waterlogging }\end{array}$ & T. сасао & $\begin{array}{c}\text { Bertolde } \\
\text { et al., } 2014\end{array}$ \\
\hline PDC & LOC18596726 & Tc06cons_t017450.1 & ttgagattcatgatggccctt & ctcctgttgctgtggatattg & 150 & 56 & $\begin{array}{l}\text { Differential } \\
\text { expression } \\
\text { during } \\
\text { waterlogging }\end{array}$ & T. сасао & $\begin{array}{c}\text { Bertolde } \\
\text { et al., } 2014\end{array}$ \\
\hline$L D H$ & LOC18606285 & Tc03cons_t024760.1 & tggctactccgtggctagct & aagacgccacccctaccaag & 150 & 60 & $\begin{array}{l}\text { Differential } \\
\text { expression } \\
\text { during } \\
\text { waterlogging }\end{array}$ & T. cacao & $\begin{array}{c}\text { Bertolde } \\
\text { et al., } 2014\end{array}$ \\
\hline$A C P B$ & CU536770 & Pinheiro et al., 2011 & gcagacaagatcagcacaa & aaatcaaagggcacgact & 192 & 52 & Housekeeping & T. сасао & $\begin{array}{c}\text { Pinheiro } \\
\text { et al., } 2011\end{array}$ \\
\hline
\end{tabular}


included negative template controls run in triplicate. RT-qPCR was performed using a volume of each cDNA equivalent to $5 \mathrm{ng}$ of reverse-transcribed total RNA and $0.25 \mu \mathrm{M}$ of each primer pair in $15 \mu$ l of final reaction volume using Luna Universal qPCR Master Mix ${ }^{\circledR}$ (New England Biolabs, MA, United States). Amplification assays were performed in a Quant Studio 3 RealTime PCR System (Applied Biosystems, CA, United States). The specificity of all amplifications was verified using melting curves and the threshold cycle values $(\mathrm{Ct})$ of the evaluated and housekeeping genes were registered to calculate the changes in relative expression using the $2^{-\Delta \Delta C t}$ method (Pfaffl, 2001). Previously, standard curves (Supplementary Figure 2) were obtained for each target gene and amplification efficiencies were calculated according to the criteria suggested by Pfaffl (2004). The expression analyses were normalized with the $A C P B$ housekeeping gene, which was the most stable across our conditions and datasets and among all housekeeping genes evaluated. (Supplementary Figure 3). Detailed protocol as well as raw data can be consulted in Supplementary Material.

\section{Statistical Analysis}

Analyses of variance (ANOVA) were performed to determine the effect of the clones and treatments on the physiological variables registered and whether there were significant differences in the relative gene expression of selected genes between clones and days after suspension of irrigation. Subsequently, a mean comparison analysis was performed to assess statistically significant differences through LSD and Tukey's HSD a posteriori tests $(P<0.05)$. The analyses were carried out using $\mathrm{R}$ software (R Studio Version 1.1.463) (R Core Team, 2019).

\section{RESULTS}

\section{Physiological Responses}

\section{Microclimatic Conditions During Measurements}

The air temperature in the glasshouse during the experiment ranged between 17 and $35^{\circ} \mathrm{C}$, with a mean value of $26^{\circ} \mathrm{C}$, and the average relative humidity was 93\% (Supplementary Figure 1A). Furthermore, the VPD ranged between 0.7 and $2.2 \mathrm{kPa}$, with a mean value of $1.3 \mathrm{kPa}$ (Supplementary Figure 1B).

\section{Leaf Water Potential}

The $\Psi_{\text {leaf }}$ value was significantly different between water states at D26 and between DS plants (Figure 1B). In the WW clones, the $\Psi_{\text {leaf }}$ value remained between -0.25 and $-0.16 \mathrm{MPa}$, while in clones under DS, a significant reduction was observed to an approximate value of $-3.0 \mathrm{MPa}$ at D26 (Table 3) when the VWC reached 6\% (Figure 1A). At D26, not all clones showed similar effect on their $\Psi_{\text {leaf }}$, and the clone that showed the highest $\Psi_{\text {leaf }}$ was THS $565(-2.06 \mathrm{MPa})$ while the clone with the lowest $\Psi_{\text {leaf }}$ was ICS95 $(-2.83 \mathrm{MPa})$. Interestingly, at $4 \mathrm{DAR}$, all clones previously submitted to DS showed similar $\Psi_{\text {leaf }}$ values to their respective control (WW) clones (between -0.183 and $-0.266 \mathrm{MPa}$ ) (Table 3). Therefore, despite experiencing severe water deficit stress of nearly one month without a water supply, all cacao clones were able to recover after rewatering, showing that they were able to tolerate this level of stress.

\section{Relative Leaf Water Content and Membrane Permeability Determination}

The RWC maintained high values in all WW clones (between 86.36 and 91.33\%). At D26, the FEAR5, ICS60, ICS95 and TSH565 clones experienced a significant decrease in RWC (Table 4), with FEAR5 showing the highest water loss (80\%). The

TABLE 3 | Leaf water potential ( $\left.\Psi_{\text {leaf }}\right)$ of the seven cacao clones under different water states.

\begin{tabular}{lccc}
\hline Clone & \multicolumn{3}{c}{$\boldsymbol{\Psi}_{\text {leaf }} \mathbf{( M P a )}$} \\
\cline { 2 - 4 } & Water states & D26 & DAR \\
\hline CCN51 & WW & $-0.1833 \pm 0.016 \mathrm{a}$ & $-0.266 \pm 0.016 \mathrm{a}$ \\
EET8 & DS & $-2.48 \pm 0.16 \mathrm{~cd}$ & $-0.200 \pm 0.0 \mathrm{a}$ \\
FEAR5 & WW & $-0.2125 \pm 0.038 \mathrm{a}$ & $-0.200 \pm 0.0 \mathrm{a}$ \\
& DS & $-2.50 \pm 0.13 \mathrm{~cd}$ & $-0.216 \pm 0.017 \mathrm{a}$ \\
ICS1 & WW & $-0.25 \pm 0.06 \mathrm{a}$ & $-0.216 \pm 0.02 \mathrm{a}$ \\
ICS60 & DS & $-2.70 \pm 0.11 \mathrm{~cd}$ & $-0.183 \pm 0.06 \mathrm{a}$ \\
& WW & $-0.20 \pm 0.06 \mathrm{a}$ & $-0.233 \pm 0.033 \mathrm{a}$ \\
ICS95 & DS & $-2.53 \pm 0.16 \mathrm{~cd}$ & $-0.250 \pm 0.050 \mathrm{a}$ \\
& WW & $-0.26 \pm 0.03 \mathrm{a}$ & $-0.166 \pm 0.066 \mathrm{a}$ \\
TSH565 & DS & $-2.33 \pm 0.32 \mathrm{bc}$ & $-0.266 \pm 0.044 \mathrm{a}$ \\
& WW & $-0.22 \pm 0.02 \mathrm{a}$ & $-0.200 \pm 0.0 \mathrm{a}$ \\
& DS & $-2.83 \pm 0.14 \mathrm{~d}$ & $-0.266 \pm 0.060 \mathrm{a}$ \\
& DW & $-0.17 \pm 0.03 \mathrm{a}$ & $-0.183 \pm 0.044 \mathrm{a}$ \\
& DS & $-2.07 \pm 0.04 \mathrm{~b}$ & $-0.223 \pm 0.060 \mathrm{a}$
\end{tabular}

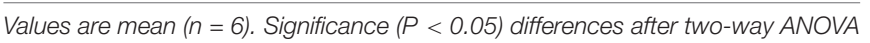
(clone $x$ treatment) and $L S D$ post hoc test results are denoted by different letters. WW, well-watered, DS, water deficit stress; D26, maximum water deficit stress of 26 days; and DAR, recovery after 4 days of rehydration after DS.

TABLE 4 | Changes in the leaf relative water content (RWC) and electrolyte linkage (EL) at D26 in the seven cacao clones.

\begin{tabular}{lccc}
\hline Clone & Water states & RWC & EL \\
\cline { 2 - 4 } & & $\mathbf{( \% )}$ & $\mathbf{( \% )}$ \\
\hline CCN51 & WW & $89.853 \pm 0.88 \mathrm{abc}$ & $16.060 \pm 1.44 \mathrm{~b}$ \\
EET8 & DS & $87.450 \pm 0.54 \mathrm{abcd}$ & $17.350 \pm 1.38 \mathrm{~b}$ \\
& WW & $86.357 \pm 1.97 \mathrm{abcde}$ & $15.280 \pm 1.40 \mathrm{~b}$ \\
FEAR5 & DS & $87.223 \pm 1.89 \mathrm{abcd}$ & $16.670 \pm 0.0 \mathrm{~b}$ \\
ICS1 & WW & $89.760 \pm 1.07 \mathrm{abc}$ & $16.380 \pm 1.14 \mathrm{~b}$ \\
& DS & $80.093 \pm 1.53 \mathrm{e}$ & $17.780 \pm 1.12 \mathrm{~b}$ \\
ICS60 & WW & $90.210 \pm 1.6 \mathrm{ab}$ & $16.563 \pm 1.62 \mathrm{~b}$ \\
ICS95 & DS & $83.780 \pm 0.54 \mathrm{bcde}$ & $23.163 \pm 2.16 \mathrm{a}$ \\
& WW & $91.333 \pm 1.29 \mathrm{a}$ & $16.557 \pm 1.76 \mathrm{~b}$ \\
TSH565 & DS & $83.143 \pm 2.79 \mathrm{cde}$ & $23.460 \pm 3.79 \mathrm{a}$ \\
& WW & $90.747 \pm 1.57 \mathrm{a}$ & $16.193 \pm 1.91 \mathrm{~b}$ \\
& DS & $81.713 \pm 4.28 \mathrm{de}$ & $19.487 \pm 2.25 \mathrm{ab}$ \\
& WW & $89.923 \pm 1.17 \mathrm{ab}$ & $15.083 \pm 0.80 \mathrm{~b}$ \\
& & $82.332 \pm 3.21 \mathrm{de}$ & $16.313 \pm 0.94 \mathrm{~b}$
\end{tabular}

Values are mean $(n=6)$. Significance differences $(P<0.05)$ after two-way ANOVA (clone $x$ treatment) and $L S D$ post hoc test results are denoted by different letters. 
other stressed clones seemed to be able to maintain RWC values similar to their cognate control plants, with EET8 and CCN51 showing the highest values (87\%), with significant differences with respect to the other clones in DS (Table 4).

In contrast, EL did not show significant differences between WW and DS in most of the clones, showing a value of $16 \%$ on average under DS, similar to all WW plants, except for the ICS1 and ICS60 clones, for which significant increases in EL upon DS were observed, reaching $23.1 \%$ and $23.4 \%$, respectively (Table 4).

\section{Leaf Gas Exchange}

As expected, DS affected leaf gas exchange, significantly reducing $A$ and $g_{s}$, while $C_{i}$ was increased significantly in all the clones evaluated (Table 5). Under WW treatment, the A values ranged from 3.4 to $5.5 \mu$ moles of $\mathrm{CO}_{2} \mathrm{~m}^{-2} \mathrm{~s}^{-1}$, while under DS, the A values were almost completely inhibited (98\% on average) at D26, reaching negative values and ranging between -0.09 and $0.086 \mu$ moles of $\mathrm{CO}_{2} \mathrm{~m}^{-2} \mathrm{~s}^{-1}$, without significant differences between clones. The negative values are indicative of net $\mathrm{CO}_{2}$ production in the light (i.e., photorespiration), which is also supported by the higher $\mathrm{C}_{i}$ concentration found under DS. Interestingly, despite reaching $\mathrm{A}$ values close to $0 \mu$ moles of $\mathrm{CO}_{2} \mathrm{~m}^{-2} \mathrm{~s}^{-1}$ at DS, the ICS1 and EET8 clones did not show negative values, even at D26 (Table 5). As mentioned above, $\mathrm{C}_{i}$ increased significantly under DS compared to WW plants as the values rose from 264 to $278 \mu \mathrm{mol} \mathrm{CO} \mathrm{mol}^{-1}$ to 356-447 $\mu \mathrm{mol} \mathrm{CO} 2 \mathrm{~mol}^{-1}$, accounting for a $45 \%$ increase in average due to DS. The highest $C_{i}$ values (447 and $416 \mu \mathrm{mol}$ $\mathrm{CO}_{2} \mathrm{~mol}^{-1}$ ) corresponded to ICS95 and FEAR5, for which the increase was 69.1 and 54.2\%, respectively, and the lowest values were found for the clones CCN51 and ICS1 (356.8 and 358 $\mu \mathrm{mol} \mathrm{CO} \mathrm{mol}^{-1}$ ), reflecting an increase of approximately $30 \%$. Notably, significant differences were found between the clones presenting the lowest values and those showing the highest values of $\mathrm{C}_{i}$ (Table 5).

Furthermore, a significant reduction in $\mathrm{g}_{s}$ (80\% on average) was observed upon DS treatment in most of the clones compared to their respective WW controls. WW $\mathrm{g}_{s}$ values varied from 0.057 to $0.089 \mathrm{~mol}$ of $\mathrm{H}_{2} \mathrm{O} \mathrm{m} \mathrm{m}^{-2} \mathrm{~s}^{-1}$, while under $\mathrm{DS}$, the $\mathrm{g}_{s}$ values ranged from 0.024 to $0.008 \mathrm{~mol}$ of $\mathrm{H}_{2} \mathrm{O} \mathrm{m}^{-2} \mathrm{~s}^{1}$.

TABLE 5 | Changes in gas exchange parameters of the seven cacao clones under different water states.

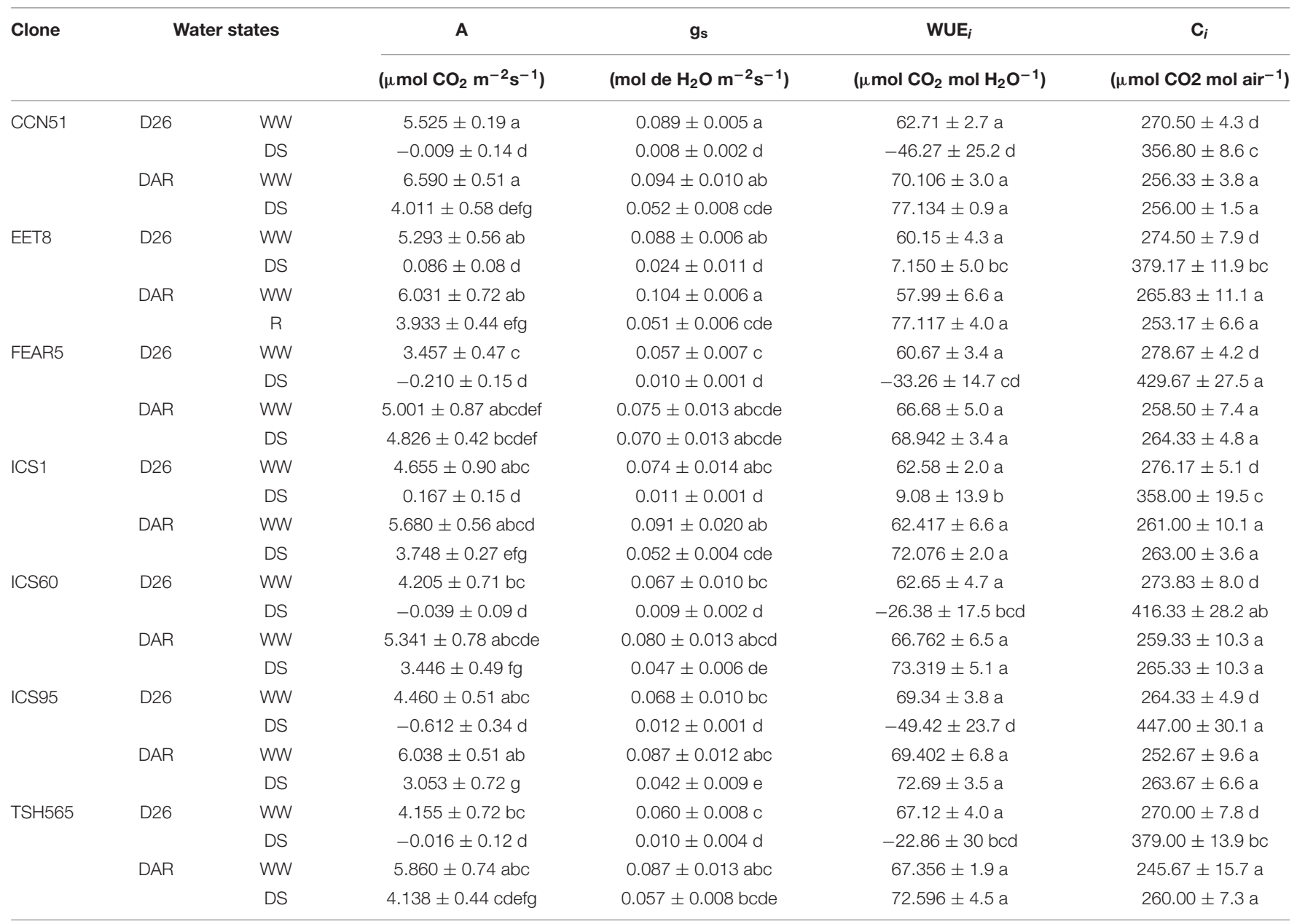

A, photosynthetic rate; $g_{s}$, stomatal conductance; $W U E_{i}$, water use efficiency; $C_{i}$, intercellular $\mathrm{CO}_{2} ; W W$, well-watered; DS, water deficit stress; D26, maximum water deficit stress of 26 days; $D A R$, recovery after 4 days of rehydration after $D S$.

Values are mean $(n=9)$. Significance differences $(P<0.05)$ after two-way ANOVA (clone $x$ treatment) and LSD post hoc test results are denoted by different letters. 
Moreover, the $\mathrm{WUE}_{i}$ was also reduced meaningfully under DS in most of the clones and reached negative values, as observed for A. Under WW conditions, the $\mathrm{WUE}_{i}$ varied between 60 and $69 \mu$ moles of $\mathrm{CO}_{2}$ mol $\mathrm{H}_{2} \mathrm{O}^{-1}$, whereas under DS, the values ranged from 7.150 to $-49.42 \mu$ moles of $\mathrm{CO}_{2} \mathrm{~mol} \mathrm{H}_{2} \mathrm{O}^{-1}$. Importantly, under DS, $\mathrm{WUE}_{i}$ was significantly higher for clones ICS1 and EET8 than for the other cacao clones that showed negative $\mathrm{WUE}_{\mathrm{i}}$ (Table 5).

Overall, the A and $\mathrm{g}_{s}$ values of DS plants recovered gradually $4 \mathrm{DAR}$, reaching an average $50 \%$ of $\mathrm{WW}$ plant values, while $\mathrm{C}_{i}$ was restored to levels similar to those found for WW control plants (Table 5). Interestingly, $\mathrm{WUE}_{i}$ reached $\mathrm{WW}$ values at 4 DAR for all clones, without significant differences between clones and treatments.

\section{Chlorophyll Fluorescence Parameters}

At D26, $\mathrm{F}_{v} / \mathrm{F}_{m}$ decreased significantly in clones under DS compared to WW clones, except for the EET8 clone, for which no significant differences were found. The reduction was in the range of 18 to $44 \%$, with $\mathrm{F}_{v} / \mathrm{F}_{m}$ values between 0.424 and 0.662 upon DS, compared with values of approximately 0.750 on average for all WW clones. ICS95 and ICS60 showed the highest reduction ( 44 and $41 \%$, respectively), and the lowest $\mathrm{F}_{v} / \mathrm{F}_{m}$ values ( 0.424 and 0.460 , respectively) were significantly different from EET8 and CCN51 (Table 6). Concerning Y[II], no significant differences were observed between treatments for EET8, CCN51, ICS1, and TSH565 at the maximum level of stress (D26), whereas under DS, ICS95, ICS60 and FEAR5 experienced a significant Y [II] reduction of 32,30 , and $24 \%$, respectively.

Regarding the effect of rehydration on the recovery of photosynthesis, all clones, including those that were more affected by DS, were able to recover values similar to their control (WW) clones without significant differences between them at 4 DAR (Table 6). In general, the response of all evaluated clones to the DS treatment seemed similar, although important differences were observed that allowed us to identify some clones with a better capacity to cope with the stress, as mentioned below.

Among the differences in the response to DS observed between clones, interestingly, the EET8 clone did not show a decrease in either the $\mathrm{F}_{v} / \mathrm{F}_{m}$ parameter or $\mathrm{Y}[\mathrm{II}]$, while the ICS60 clone was one of the most affected clones in these two parameters together with a significant increase in EL, as stated above. The impact of these three parameters, particularly $\mathrm{F}_{v} / \mathrm{F}_{m}$, could reflect photoinhibition by oxidation, assessing the existence of this condition to be relevant in T. cacao. Therefore, to determine both the extent of this probable oxidative stress induced under DS and whether different cacao clones responded differently regarding the activation of their antioxidant system, gene expression profiling was carried out on three selected cacao clones: the two most contrasting clones with regard to their photosynthetic and chlorophyll fluorescence parameters, as well as the EL parameters (EET8 and ICS60), together with the TSH565 clone, which maintained the highest water potential under DS.

\section{Drought and Oxidative Stress-Related Gene Expression Profiling}

The genes used to evaluate the activation of an oxidative stress response under DS in T. cacao (Table 2) were grouped into three
TABLE 6 | Changes in the maximum quantum yield of PSII $\left(F_{v} / F_{m}\right)$ and effective quantum yield of PSII (Y (II)) of cacao clones under different water states.

\begin{tabular}{|c|c|c|c|c|}
\hline \multirow{2}{*}{$\begin{array}{l}\text { Clone } \\
\text { CCN51 }\end{array}$} & \multicolumn{2}{|c|}{ Water states } & \multirow{2}{*}{$\begin{array}{c}\mathbf{F}_{\boldsymbol{v}} / \mathbf{F}_{\boldsymbol{m}} \\
0.767 \pm 0.007 \mathrm{a}\end{array}$} & \multirow{2}{*}{$\begin{array}{c}\text { Y (II) } \\
0.447 \pm 0.012 \mathrm{a}\end{array}$} \\
\hline & D26 & WW & & \\
\hline & & DS & $0.613 \pm 0.05 \mathrm{~cd}$ & $0.397 \pm 0.033 a b c$ \\
\hline & DAR & WW & $0.743 \pm 0.013 a b c$ & $0.489 \pm 0.014 \mathrm{ab}$ \\
\hline & & DS & $0.685 \pm 0.031 \mathrm{cde}$ & $0.405 \pm 0.016 \mathrm{e}$ \\
\hline \multirow[t]{4}{*}{ EET8 } & D26 & WW & $0.756 \pm 0.021 \mathrm{ab}$ & $0.434 \pm 0.005 a b$ \\
\hline & & DS & $0.622 \pm 0.042 \mathrm{bcd}$ & $0.382 \pm 0.054 \mathrm{abcd}$ \\
\hline & DAR & WW & $0.757 \pm 0.023 \mathrm{a}$ & $0.441 \pm 0.010$ cde \\
\hline & & DS & $0.665 \pm 0.025 \mathrm{de}$ & $0.435 \pm 0.008$ cde \\
\hline \multirow[t]{4}{*}{ FEAR5 } & D26 & WW & $0.740 \pm 0.010 \mathrm{abc}$ & $0.450 \pm 0.016 \mathrm{a}$ \\
\hline & & DS & $0.556 \pm 0.047 \mathrm{de}$ & $0.341 \pm 0.049 \mathrm{bcd}$ \\
\hline & DAR & WW & $0.757 \pm 0.011 \mathrm{a}$ & $0.452 \pm 0.012 \mathrm{bcd}$ \\
\hline & & DS & $0.696 \pm 0.035$ abcde & $0.408 \pm 0.026 \mathrm{de}$ \\
\hline \multirow[t]{4}{*}{ ICS1 } & D26 & WW & $0.760 \pm 0.007 \mathrm{a}$ & $0.454 \pm 0.023 \mathrm{a}$ \\
\hline & & DS & $0.502 \pm 0.007 \mathrm{de}$ & $0.384 \pm 0.033 \mathrm{abcd}$ \\
\hline & DAR & WW & $0.7485 \pm 0.017 \mathrm{abc}$ & $0.476 \pm 0.016 \mathrm{abc}$ \\
\hline & & DS & $0.700 \pm 0.032$ abcde & $0.436 \pm 0.016 \mathrm{cde}$ \\
\hline \multirow[t]{4}{*}{ ICS60 } & D26 & WW & $0.791 \pm 0.016 a$ & $0.432 \pm 0.008 \mathrm{ab}$ \\
\hline & & DS & $0.460 \pm 0.062 \mathrm{e}$ & $0.301 \pm 0.053 \mathrm{~cd}$ \\
\hline & DAR & WW & $0.755 \pm 0.003 \mathrm{ab}$ & $0.438 \pm 0.020$ cde \\
\hline & & DS & $0.689 \pm 0.025$ bcde & $0.429 \pm 0.023 \mathrm{de}$ \\
\hline \multirow[t]{4}{*}{ ICS95 } & D26 & WW & $0.758 \pm 0.009 a$ & $0.436 \pm 0.005 a b$ \\
\hline & & DS & $0.424 \pm 0.108 \mathrm{e}$ & $0.295 \pm 0.074 d$ \\
\hline & DAR & WW & $0.752 \pm 0.021 \mathrm{abc}$ & $0.442 \pm 0.012$ cde \\
\hline & & DS & $0.7130 \pm 0.009 \mathrm{abcd}$ & $0.438 \pm 0.019$ cde \\
\hline \multirow[t]{4}{*}{ TSH565 } & D26 & WW & $0.752 \pm 0.011 \mathrm{ab}$ & $0.472 \pm 0.012 \mathrm{a}$ \\
\hline & & DS & $0.523 \pm 0.047$ de & $0.441 \pm 0.016 \mathrm{ab}$ \\
\hline & DAR & WW & $0.721 \pm 0.021 \mathrm{abcd}$ & $0.500 \pm 0.014 a$ \\
\hline & & DS & $0.634 \pm 0.037 \mathrm{e}$ & $0.427 \pm 0.008$ de \\
\hline
\end{tabular}

WW, well-watered; DS, water deficit stress; D26, maximum water deficit stress of 26 days; $D A R$, recovery after 4 days of rehydration after $D S$.

Values are mean $(n=9)$. Significance differences $(P<0.05)$ after two-way ANOVA (clone $x$ treatment) and $L S D$ post hoc test results are denoted by different letters.

categories according to the function to which they have been associated according to the literature: (1) markers of oxidative stress (Noctor, 2006), (2) crosstalk between water deficit and oxidative stress (Noctor, 2006; Chaouch et al., 2012; Sheoran et al., 2015; Morales et al., 2016; Kim et al., 2017), and (3) a possible switch to fermentative metabolism (Bertolde et al., 2014). Furthermore, to observe the progressive change in the expression patterns of these genes in response to the severity of water deficit, these genes were evaluated before, near to the end and at the end or maximum level of DS, which corresponded to days 0,23 , and 26 , respectively.

\section{Oxidative Stress Markers GST and HSP}

Significant differences in the expression patterns of these two oxidative stress markers were found after water deprivation in all three clones evaluated (Figure 2). Interestingly, strong upregulation was observed at D23 in all clones, and it was significantly reduced or undetectable at the maximum stress level (D26). Although no significant differences were found between clones for GST expression profiles, at D26, EET8 was the only clone to maintain induction of both GST and HSP genes 
A

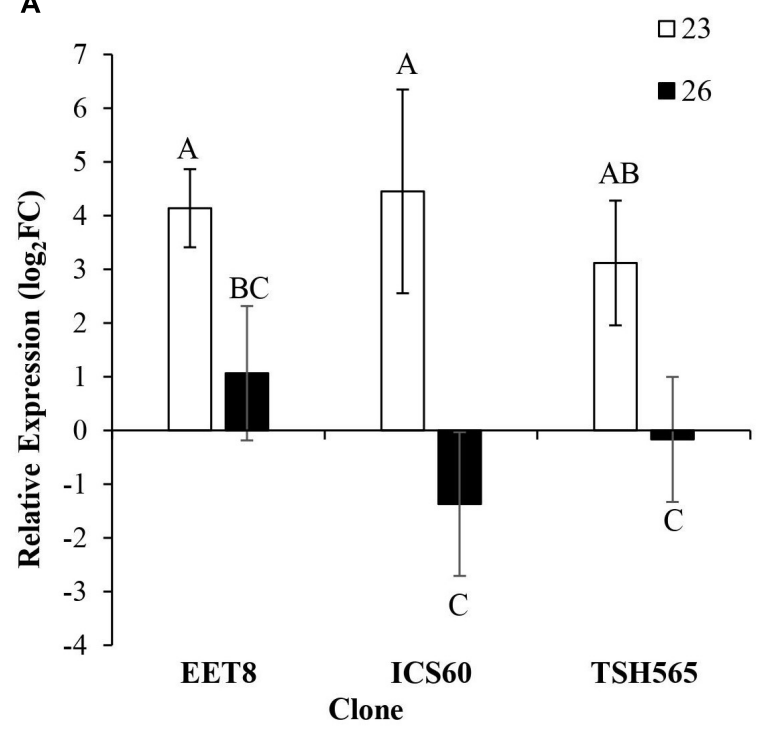

B

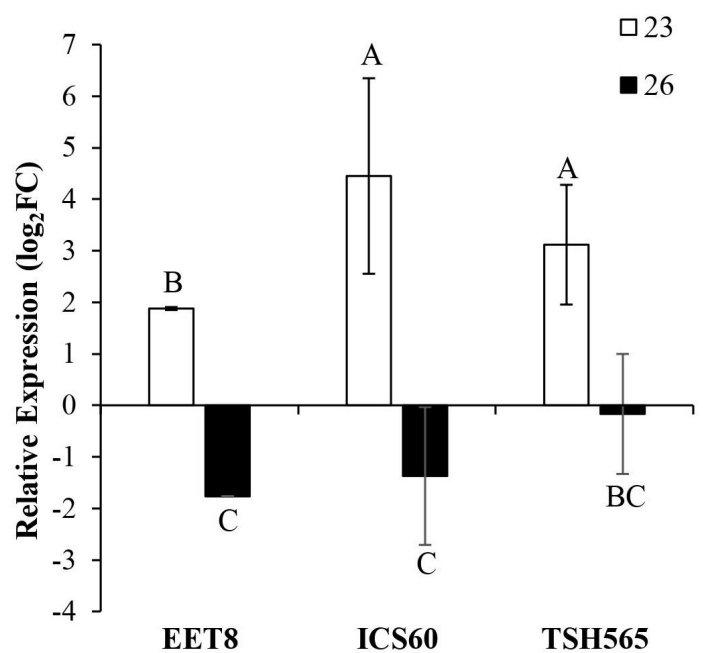

Clone

FIGURE 2 | Effect of water deficit on the transcriptional expression of oxidative stress markers. (A) GST. (B) Hsp17.6. Bars represent the averages of the induction factor (log2-fold change) \pm standard deviation $(n=3)$ relative to the control (day 0$)$. The letters indicate statistically significant differences between days 23 and 26 of water deficit $(P<0.05)$.

compared to both ICS60 and TSH565 clones, which showed a downregulation pattern at the maximum level of DS (D26). In contrast, for the HSP gene, the upregulation observed at D23 was significantly higher in ICS60 and TSH565 clones than in EET8 clones. Although there were few differences in the expression profiles between clones, the strong induction of both oxidative stress markers observed at D23 before the maximum level of stress suggests that DS triggered oxidative stress in all cacao clones

\section{Crosstalk Between Water Deficit and Oxidative Stress}

Furthermore, genes encoding enzymes of the antioxidant system (RBOHF, NTRC, UDPGT, and SOD) were analyzed according to their expression profile in response to DS in cacao. In general, all genes showed a similar pattern to that found for GST and $H S P$, i.e., a significant induction at D23 in all clones (Figure 3), except for TSH565, which presented a downregulation of NTRC expression at this point (Figure 3B). Interestingly, $R B O H F$, UDPGT, and SOD showed greater induction in the ICS60 clone than in the other clones. Nonetheless, the UDPGT induction levels were significantly higher in ICS60 followed by EET8, and the lowest induction was observed for TSH565 (Figure 3C). Finally, as observed for GST and HSP, most genes experienced a reversion of this upregulation in all clones at D26, except for SOD in TSH565 and EET8 clones in which this ROS transcript maintained an upregulated state at this point, while in ICS60, it showed a significant reduction between D23 and D26 (Figure 3D).

\section{Possible Switch to Fermentative Metabolism}

Interestingly, the expression patterns of fermentative enzymes coding transcripts showed similar general behavior to that observed for antioxidant enzymes, i.e., they all presented a significant upregulation at D23 in the three clones except for the PDC transcript in TSH565, which was downregulated (Figure 4). Induction patterns at D23 presented differences between clones for $L D H$ and $P D C$ transcripts, and in both cases, a significantly higher level of induction was found for ICS60. In contrast, no differences in induction levels were found for $A D H$ transcripts between the three clones. Finally, as observed for most of the antioxidant enzymes, reversion of this upregulation at D26 was presented for $L D H$ and $P D C$ transcripts in all clones, whereas $A D H$ induction seemed maintained in all clones, although a significant reduction was observed in ICS60 (Figure 4C).

\section{DISCUSSION}

\section{Physiological Responses of Cacao Clones to Drought}

This research aimed to characterize and compare the physiological responses of seven commercial cacao clones. Our results show some clear differences between clones, reflecting different levels of tolerance among them, although all clones were able to recover from a pronounced water deficit stress of 26 days long. One key variable that is typically recorded in plants under drought conditions and which is directly associated with tolerance to DS is $\Psi_{\text {leaf }}$ because it indicates the plant water status and the plant's ability to uptake soil water and avoid water loss (dehydration) (Bray, 1997; Rodríguez et al., 2017). In this study, $\Psi_{\text {leaf }}$ decreased in all cacao clones to values below $-2.3 \mathrm{MPa}$ at the maximum level of DS (D26). However, the TSH565 clone showed the highest $\Psi_{\text {leaf }}$ value $(-2.07 \mathrm{MPa})$, indicating 
A

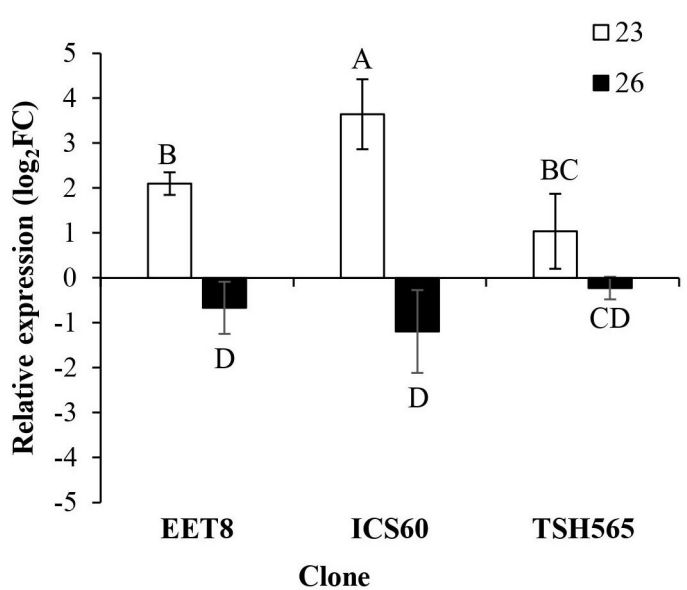

C

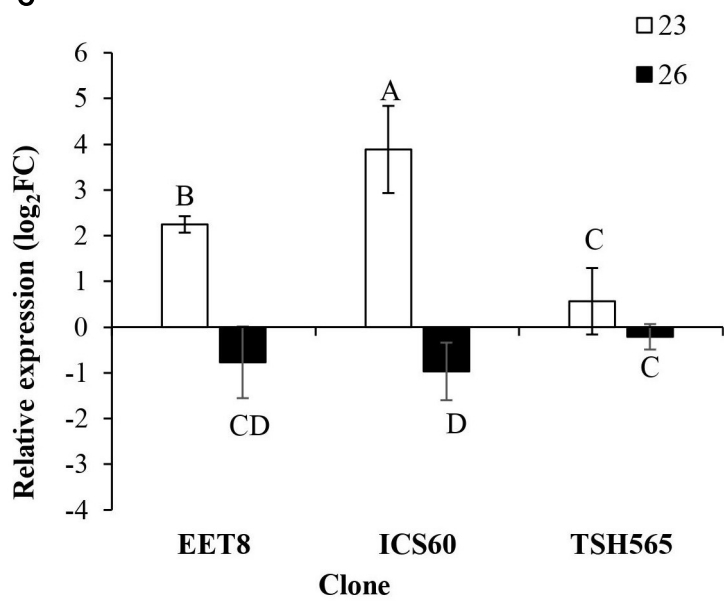

B

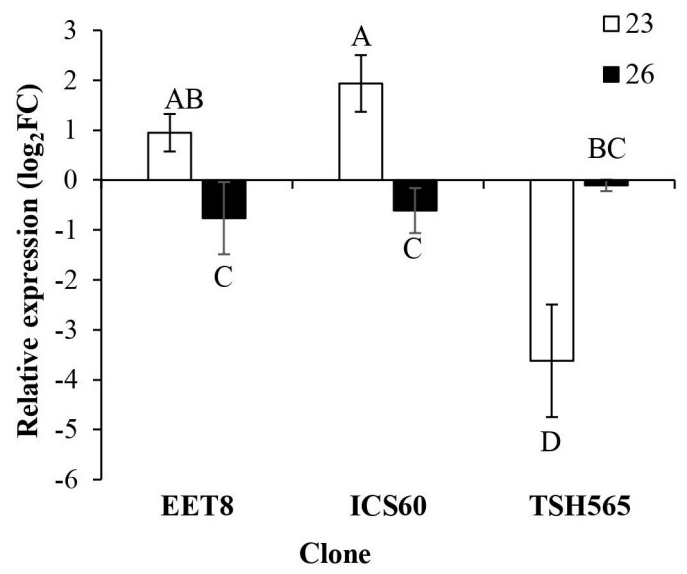

D

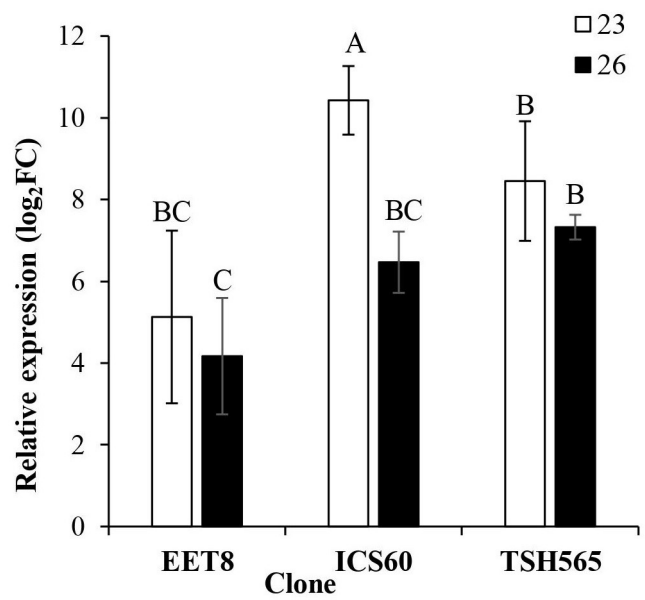

FIGURE 3 | Effect of water deficit on the transcriptional expression of genes encoding antioxidant enzymes. (A) RBOHF. (B) NTRC. (C) UDPGT. (D) SOD. Bars represent the averages of the induction factor (log2-fold change) \pm standard deviation $(n=3)$ relative to the control (day 0 ). The letters indicate statistically significant differences between days 23 and 26 of water deficit $(P<0.05)$.

that it was less affected than the rest of the clones (Table 3), which suggests a higher capacity of this clone to maintain water homeostasis in the leaf tissues and cell turgor under severe water deficit. Balasimha et al. (1991) noted that drought-tolerant cacao genotypes were able to maintain less negative $\Psi_{\text {leaf }}$ during the driest months of the year. Therefore, this ability shown in the TSH565 clone indicates that this genotype is tolerant to water deficit stress (Balasimha et al., 1991, 2013; Medina and Laliberte, 2017). Moreover, this reduction in $\Psi_{\text {leaf }}$ under limiting conditions is related to the low availability of water in the soil since the VWC of the soil dropped gradually to $6 \%$ after suspending the plant irrigation (Figure 1A). García Lozano and Moreno Fonseca (2016) reported that at 10\% VWC, the soil lacks available water for plants, and Medina and Laliberte (2017) proposed that in cacao, severe stress occurs below water potential values of $-1.76 \mathrm{MPa}$. Our results are consistent with previous studies carried out in cacao and report that the reduction in $\Psi_{\text {leaf }}$ to values below -1.3 MPa (García Lozano and Moreno Fonseca,
2016) is a direct consequence of the reduction in the soil VWC caused by periods of drought (Alban et al., 2016; De Almeida et al., 2016; García Lozano and Moreno Fonseca, 2016; Lahive et al., 2019). Indeed, upon rewatering at $4 \mathrm{DAR}$, the cacao clones restored $\Psi_{\text {leaf }}$ to values close to those of WW plants (Figure 1B).

In addition, it has been observed that reduced water supply impacts cacao growth and development through a reduction in the leaf area, which leads to lower net assimilation, stomatal conductance, and yield, being this reduction of leaf area considered one of the earliest acclimation mechanisms to withstand drought (Ayegboyin and Akinrinde, 2016). Impact of DS in cacao leaf area was addressed in a different study in which only ICS60, TSH565 and EET8 clones were monitored: a significant reduction in the leaf area upon DS was observed, without differences between clones. However, TSH565 had the lesser reduction (47\%) with respect to its control (WW) plants, while EET8 and ICS60 clones showed a reduction in leaf area of 72\% (Osorio-Zambrano, 2021). Thus, TSH565 response could 

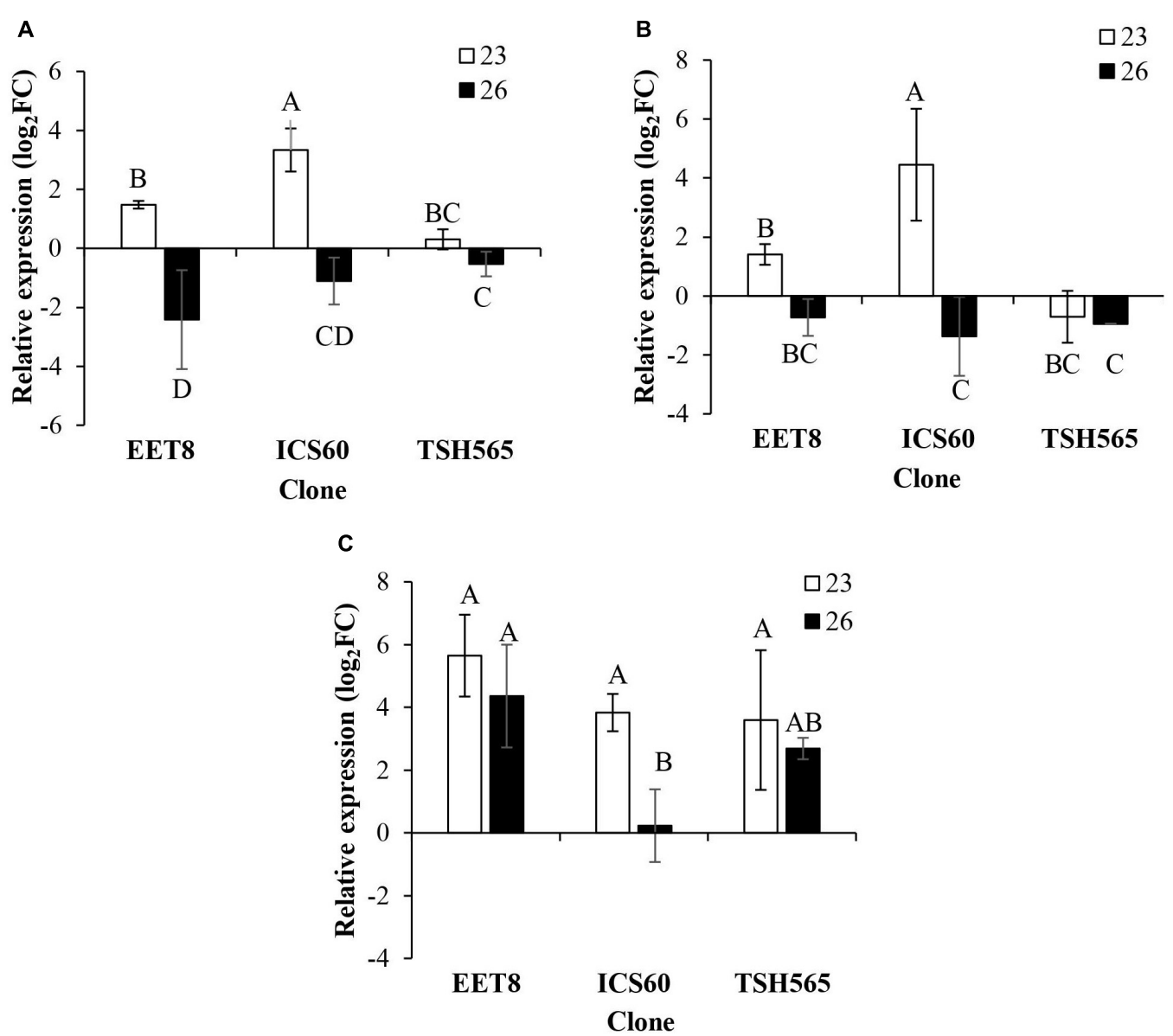

FIGURE 4 | Effect of water deficit on the transcriptional expression of genes encoding fermentative metabolism enzymes. (A) $L D H$. (B) $P D C$. (C) $A D H$. Bars represent the averages of the induction factor (log2-fold change) \pm standard deviation $(n=3)$ relative to the control (day 0$)$. The letters indicate statistically significant differences between days 23 and 26 of water deficit $(P<0.05)$.

be related with the ability of this clone to cope with water deficit stress by maintaining higher water potential, as has been observed here.

In previous research, stomatal sensitivity for regulating water loss has also been proposed as an important physiological trait of adaptation to drought stress, as it may reflect a better ability to cope with DS during the resulting acclimation response of the plant and represents the main mechanism to efficiently control water equilibrium and avoid water loss by transpiration (Almeida and Valle, 2007; Apshara et al., 2013). However, because of the strong impact of the evaporative demand of the atmosphere (FAO, 2006; García Lozano and Moreno Fonseca, 2016; Merilo et al., 2018; Lahive et al., 2019), during the experiment time course, microclimatic variables were monitored to evaluate their influence on physiological parameters. Although VPD tended to increase with temperature accordingly, the VPD mean value (1.3 $\mathrm{kPa}$ ) indicated that evaporative demand did not contribute to a decrease in $\mathrm{g}_{s}$ or $\mathrm{A}$ in the plants, since the normal stomatal closure values in cacao are close to $1.8 \mathrm{KPa}$ as reported previously (García Lozano and Moreno Fonseca, 2016). Indeed, in T. cacao plants, increases in VPD caused a linear decrease in $\mathrm{g}_{s}$; however, A only decreased at VPD values up to $2.0 \mathrm{kPa}$ (Balasimha et al., 1991; Almeida and Valle, 2007; Baligar et al., 2008; García Lozano and Moreno Fonseca, 2016; Lahive et al., 2019), a threshold that was not reached in our experimental time course.

Furthermore, the reduction in $\mathrm{g}_{s}$ under DS, as a direct consequence of stomatal closure and despite being an acclimation response of plants (Osakabe et al., 2014), is also considered a trait related to tolerance, as it is part of the avoidance response mechanism to reduce water loss by transpiration under water deficit and thus to maintain RWC, which prevents tissue damage (Gupta et al., 2020). In the current study, the reduction in $\mathrm{g}_{s}$ by almost $80 \%$ in all cacao clones evaluated (Table 5) suggests a stomatal-sensitive response for the regulation of water loss by transpiration, with the consequent reduction in $\mathrm{A}$ due to the reduction in $\mathrm{CO}_{2}$ uptake. Despite these similarities between clones, EET8 showed the highest $\mathrm{g}_{s}$ at D26 under DS (Table 5), which may have influenced the maintenance of higher $\mathrm{CO}_{2}$ assimilation, as reflected both by a positive A compared to the other clones as well as a higher $\mathrm{F}_{v} / \mathrm{F}_{m}$ value reflecting no effect of PSII photochemical activity under DS. In contrast, the ICS60 clone exhibited the highest reduction in $\mathrm{g}_{s}$ together with a 
negative A value under DS, indicative of photorespiration and no net carbon assimilation, clearly showing a reduced performance of this clone under DS and therefore a lesser stress tolerance (Apshara et al., 2013; Balasimha et al., 2013).

This stomatal-driven decrease in $\mathrm{A}$ and $\mathrm{g}_{s}$ near and below zero values at D26 in cacao clones is consistent with previous studies on the response of cacao to DS (Ismail et al., 1992; Rada et al., 2005; Araque et al., 2012; Acheampong et al., 2013; De Almeida et al., 2016). In addition, the negative values were linked to the high rate of photorespiration found in cacao due to the high point of $\mathrm{CO}_{2}$ compensation exhibited and attributed to a possible photoprotective role (Avila-Lovera et al., 2016). These studies were carried out in greenhouses and fields with young and adult plants, and drought treatments were imposed and caused by the dry season, respectively. Furthermore, Joly and Hahn (1989) mentioned that under severe water deficit stress, $\mathrm{CO}_{2}$ assimilation drops notably, reaching zero due to turgor loss and becoming negative when respiration overtakes photosynthesis.

Finally, our findings are in accordance with a previous study where different trinitarian cacao hybrids (TSH clones) were evaluated (Antwi et al., 1994), and the most tolerant clone to DS showed little or no change in $\mathrm{g}_{s}$ and $\mathrm{E}$ while the most susceptible clones to DS presented earlier declines in $\mathrm{g}_{s}$. Among the evaluated clones, TSH919 was proposed as the most tolerant to DS based on its higher $\Psi_{\text {leaf }}$ under stress conditions, thus corroborating the use of this parameter as key for the DS tolerance ranking of cacao clones. Cacao adult trees growing in the field displayed a similar behavior, with a significant reduction in $\Psi_{\text {leaf }}$, A, and $\mathrm{g}_{s}$ upon DS, however, it has been observed that this reduction could be less pronounced than in a glasshouse, due to a higher soil water content during the dry season. Under this scenario, the root system could delay the sensing of water deficit, although a smaller decrease in $\Psi_{\text {leaf }}$ during dry season is considered a drought-tolerance trait (Balasimha et al., 1991; Rada et al., 2005; Araque et al., 2012; Avila-Lovera et al., 2016; De Almeida et al., 2016).

As mentioned above, the observed stomatal closure allowed it to keep the RWC above $80 \%$ in all clones at D26 under DS, thus maintaining leaf turgor and preventing tissue damage, which is a known mechanism of DS avoidance. Similar responses have been found in other cacao clones exposed to water deficit without a reduction in RWC (Almeida et al., 2002; Rada et al., 2005; Almeida and Valle, 2007; De Almeida et al., 2016). This ability has also been attributed to an osmotic adjustment mechanism, which contributes to maintaining leaf hydration and cell turgor during DS (Medina and Laliberte, 2017). A similar behavior was observed in coffee cultivars submitted to drought stress, whose capacity to recover from dehydration was related to osmotic adjustment triggered by the accumulation of proline and other compatible osmolytes (Tounekti et al., 2018). Additionally, this mechanism may be involved in the maintenance of membrane structural integrity and prevention of oxidative damage by scavenging ROS, which induce oxidative degradation of the lipid bilayer, thus causing electrolyte leakage. Therefore, its activation under DS may prevent essential solutes from leaking out (Villar-Salvador et al., 2004; Valentovic et al., 2006; Parkash and Singh, 2020). Complementary biochemical analyses aiming at quantifying the accumulation of compatible solutes or the activation of their cognate biosynthetic genes are needed to corroborate this probable osmoregulation response (Almeida and Valle, 2007; Araque et al., 2012).

Equally important, the $\mathrm{WUE}_{i}$, a variable that relates $\mathrm{A}$ and $g_{s}$ (Daymond et al., 2011; Lahive et al., 2019), indicates the water uptake by roots with minimal stomatal opening and thus less water loss through transpiration. It is also an indicator of the maintenance of atmospheric $\mathrm{CO}_{2}$ assimilation and thus photosynthesis. Therefore, it is also considered a key variable often associated with drought tolerance when comparing genotypes (Alban et al., 2016). In the current study, $\mathrm{WUE}_{i}$ was markedly reduced under DS in all cacao clones compared to the WW plants. However, at D26, the ICS1 and EET8 clones presented higher $\mathrm{WUE}_{i}$, which suggests that these two clones have developed mechanisms to optimize the balance between ensuring a minimal photosynthetic rate and reducing water loss through transpiration, both dependent on $\mathrm{g}_{s}$ reduction. This capacity of a genotype to maintain carbon assimilation and photosynthesis under reduced water availability is reflected in a high $\mathrm{WUE}_{i}$ and indicative of a higher stress tolerance (Daymond et al., 2011). Conversely, the reduction in $\mathrm{WUE}_{i}$ has been attributed to severe stress status, possible damage to the photosynthetic apparatus or oxidative stress occurrence (Lahive et al., 2019). Interestingly, variation (i.e., increase or decrease) in $\mathrm{WUE}_{i}$ in response to drought seems to be a genotype-dependent trait, which has been observed previously and was also the case in our study (Araque et al., 2012; Almeida et al., 2014; Avila-Lovera et al., 2016; Lahive et al., 2019).

In addition to and related to the relationship between carbon fixation and stomatal closure, the $\mathrm{C}_{i}$ parameter also appears to be a good indicator of the rate of effective $\mathrm{CO}_{2}$ consumption under stomatal conductance limitation: accordingly, under DS, EET8 presented lower $\mathrm{C}_{i}$ values than ICS60, indicating a higher $\mathrm{CO}_{2}$ consumption rate, allowed by a higher $\mathrm{g}_{s}$, and reflected in the higher photosynthetic performance (A) observed for the EET8 clone compared to ICS60.

Altogether, the above results clearly support that the cacao response to water deficit is strongly governed by stomatal conductance, as the first limiting factor of photosynthetic performance under DS, with the consequent drop in A, as has been previously reported for other cacao genotypes (De Almeida et al., 2016). This is likely to be an early and efficient mechanism encountered in several other tropical perennial crops like mango, coffee or avocado (Damour et al., 2009; Ramalho et al., 2018; Tounekti et al., 2018; Martínez-Ferri et al., 2019), as well as temperate deciduous trees such as peach or apple (Liu et al., 2012; Jiménez et al., 2013). However, our results related to chlorophyll fluorescence showed also a reduction in both $\mathrm{F}_{v} / \mathrm{F}_{m}$ and $\mathrm{Y}$ [II] values upon DS in clones that exhibited a lesser tolerance based on water status or gas exchange parameters (i.e., ICS60 and ICS95). In contrast, stressed EET8 clones showed $\mathrm{F}_{v} / \mathrm{F}_{m}$ and $\mathrm{Y}[\mathrm{II}]$ values similar to those obtained in their cognate $\mathrm{WW}$ controls. $\mathrm{F}_{v} / \mathrm{F}_{m}$ reduction has been related to a photoinhibition phenomenon, with the concomitant reduction in $\mathrm{Y}[\mathrm{II}]$ and increase in $\mathrm{C}_{i}$. The cacao response to DS may therefore have two limiting phases depending on the genotype: one initial and 
stomatal-controlled phase, resulting in a substantial reduction in $\mathrm{A}$ and $\mathrm{C}_{i}$ as $\mathrm{g}_{s}$ decreased, followed by a second and strongly photosynthetically limited phase that caused an increase of $\mathrm{C}_{i}$ while $\mathrm{F}_{v} / \mathrm{F}_{m}$ and $\mathrm{Y}[\mathrm{II}]$ decreased as an indication of the onset of non-reversible photoinhibition and photosynthetic apparatus damage. These two sequential phases have been described in the response to severe DS in other woody and perennial crops (Brodribb, 1996; Damour et al., 2009; Tounekti et al., 2018). A similar response was found in previous studies carried out with other cacao clones submitted to DS, either in glasshouse or field conditions, and with different light intensity regimes (i.e., sunlight or shade light): in all cases, a reduction in $\mathrm{F}_{v} / \mathrm{F}_{m}$ to values between 0.2 and 0.7 and a concomitant reduction in Y[II] were observed (Araque et al., 2012; Acheampong et al., 2013; Balasimha et al., 2013; Alban et al., 2016; Kumar and Jegadeeswari, 2019). According to Baker (2008), plants without chronic photoinhibition present $\mathrm{F}_{v} / \mathrm{F}_{m}$ values in the range of 0.71 to 0.83 and oxidative damage is observed when basal fluorescence increases and $\mathrm{F}_{v} / \mathrm{F}_{m}$ values are below 0.6 , as observed in most of the clones under DS in our present study. The rapid loss of PSII photochemical efficiency, as a result of water deficit, has been attributed to possible damage to the PSII light-harvesting complex caused by stress-induced oxidative burst, increased leaf chlorosis or decreased root carbohydrate concentrations, with subsequent plant death (Bertolde et al., 2012, 2014; Sharma et al., 2020). However, all evaluated clones were able to recover rapidly, reaching values of $\mathrm{F}_{v} / \mathrm{F}_{m}$ at $4 \mathrm{DAR}$ either similar or higher than WW plants, indicating that the observed drop in photosystem efficiency and possible damage were reversible, even after maximum DS. This response could be related to oxidative stress, photoinhibition and metabolic changes that together trigger plant photoprotective mechanisms as well as water homeostasis and energetic metabolism maintenance rather than irreversible damage (Bhattacharjee and Saha, 2014). Efficient PSII repair mechanisms, such as through the activation of D1 protein turnover or size adjustment of the photosynthetic antenna by the degradation of chlorophyll-binding proteins, as a preventive mechanism of photoinhibition, and activation of the antioxidant system, are considered key tolerance mechanisms of plants to DS (Knopf and Adam, 2018) because they can lead to a complete recovery of plant photosynthesis.

Furthermore, rapid inhibition of photochemistry with irreversible damage to the photosynthetic apparatus occurs in plants that cannot recover predrought levels of $\mathrm{A}$ and show visual signs of leaf damage or senescence after continued drought (Brodribb, 1996). In our case, the overall values of A, $\mathrm{F}_{v} / \mathrm{F}_{m}$ and $\mathrm{Y}[\mathrm{II}]$, which are marked by a fast recovery of the predrought state and observed for all cacao clones, could strongly suggest the activation of the abovementioned efficient damage repair mechanisms.

Finally, EL is an indicator associated with membrane integrity and stability that has also been linked to drought tolerance (Bajji et al., 2002; Souza et al., 2014). This physiological parameter has also been related to osmotic adjustment because it can prevent damage to the membrane and the consequent loss of electrolytes and contributes to cellular turgor maintenance. Specifically, all cacao clones showed similar responses and were able to maintain cell turgor and consequently membrane integrity without electrolyte leakage through leaf mesophyll cells, which could be related to the osmotic adjustment mechanism (VillarSalvador et al., 2004; Parkash and Singh, 2020). In the case of ICS60 and ICS1 clones, the slight increase observed in EL could indicate possible DS-induced membrane damage, which may have occurred by lipid peroxidation due to ROS formation and oxidative stress response, a phenomenon also found in cacao seedlings subjected to $\mathrm{Cu}$ toxicity (Souza et al., 2014). Similarly, several parameters indicated the ICS60 clone appears to be more affected by DS and therefore more susceptible than the other clones.

Overall, the above-discussed results concerning the physiological response of cacao clones to DS suggest that the exposure time to water stress by suspension of irrigation for 26 days represented severe water deficit stress for all clones evaluated. Although all clones were able to recover quickly (at 4 DAR), the results provided insights indicating that the clones presented differences in their responses related to their capacity to tolerate DS, at least under our experimental conditions. Thus, our results indicate that the EET8 clone was the most performant under DS, whereas ICS60 was seemingly the less tolerant. These differences could reflect changes in acclimation responses, which in turn could be either genetically or epigenetically dependent (Shinozaki et al., 2017).

On the other hand, as photoinhibition mechanisms were observed under DS, which suggests secondary oxidative stress induction, a preliminary approach to the activation of the antioxidant system at the transcriptional level was carried out in these clones to complement these findings.

Besides, considering that grafting practice is frequently used to integrate traits of interest between the rootstock and the scion, which in cacao is mainly destinated to confer disease resistance (Ribeiro et al., 2016), and that the rootstock could alter scion responses to various biotic and abiotic factors (Jiménez et al., 2013; Serra et al., 2014; Martínez-Ferri et al., 2019; Kapazoglou et al., 2021), it is possible that the responses observed here could have been influenced by the root-scion interaction. This may have contributed either to certain variability within each clone, due to the genetic variability of the sexually propagated rootstock, or to a more similar behavior between clones, due to the use of the same rootstock. Although the aim of this study was to compare the physiological response of grafted clonal materials, which is the most widespread propagation practice, addressing more specifically the effect of root/scion interaction on cacao response or tolerance to water deficit becomes relevant for future studies, as shown by some researches in progress (Ayegboyin, 2012; Medina and Laliberte, 2017; Lahive et al., 2019).

\section{Oxidative Stress Response Gene Expression Profile}

Only the EET8, ICS60, and TSH565 clones and leaf organ responses were evaluated in this section, since they showed most of the differences in behavior according to photosynthetic parameters, as well as in water potential. Interestingly, our gene expression profiling results appeared to confirm that 
photochemical (nonstomatal limited) reactions were affected and that a typical oxidative stress response occurred in cacao upon DS. Indeed, gene activation related to oxidative stress-related genes was seemingly directed to protect leaf cells because the expression of canonical oxidative stress repair marker genes GST and HSP showed high induction in the three clones evaluated at D23, which likely had a much earlier induction. This finding could be related to an effort of cacao plants to prevent or attenuate the negative effects of ROS increase triggered by the DS imposed. This activation has been reported as an early response induced in plants to protect protein structures and lipids against possible damage caused by ROS and tends to accumulate as a consequence of photorespiration (Chen et al., 2019; Laxa et al., 2019; Sharma et al., 2019).

As stated above, this kind of damage was also evidenced by the low values of $\mathrm{F}_{v} / \mathrm{F}_{m}$, which likely affected $\mathrm{A}$, and the drop in $\mathrm{g}_{s}$, with both responses evidenced during DS. GST is a key enzyme in ROS detoxification due to its conjugation with glutathione (Dixon and Edwards, 2005; Ding et al., 2017; Gullner et al., 2018), its relationship with the enzyme glutathione peroxidase and the detoxification of lipidic hydroperoxides (Gullner et al., 2018). The induction of GST expression has been linked as an early and key mechanism in Arabidopsis, wheat and tobacco for ROS detoxification triggered by abiotic stress (Ezaki et al., 2004; Noctor et al., 2016; Chen et al., 2019). In addition, Hsp17.6 belongs to the small heat shock protein family and is mainly found in plants and linked to ROS tolerance because it protects enzymes related to the maintenance of metabolic pathways encoded by either housekeeping or stress-related genes (Kotak et al., 2007; Park and Seo, 2015; Mishra et al., 2018). Therefore, the upregulation of Hsp17.6 has been described as a molecular signature indicating the severity of oxidative stress (Al-Whaibi, 2011; Noctor et al., 2016; Mishra et al., 2018). Although these oxidative stress markers were induced under DS in all three clones evaluated, the EET8 clone presented the lowest induction fold change in both genes, suggesting that the oxidative burst or adverse intracellular damages to repair were reduced in this clone compared to the others, accordingly with its respective physiological behavior, as discussed previously.

Similarly, RBOHF showed a significant induction at D23 in all three evaluated clones, interestingly not maintained at D26, when the maximum level of DS was reached. This expression pattern (i.e., a strong induction followed by a downregulation) may indicate that the transcriptional activation of this pathway in T. cacao could have happened earlier, even before D23, when the water status-related physiological parameters started to decrease and the related stress was perceived systemically by the plant. Moreover, this early upregulation could also be related to the physiological regulation of the stress response since the $R B O H F$ protein exerts regulatory functions on $\mathrm{ABA}$, the master mediator of the systemic response to DS (Kwak et al., 2006; Osakabe et al., 2014). Among its several plant regulatory functions, ABA influences guard cell turgor and therefore regulates stomatal closure (Kwak et al., 2006; Mittler and Blumwald, 2015), which is essential to reducing water loss, which was observed in all the cacao clones evaluated (Table 5). The downregulation of $R B O H F$ at D26 was observed after a previous activation, and it is a common pattern of expression found for many stress-response genes and does not necessarily reflect either the cognate protein level or its activity. Nevertheless, such a pattern more likely obeys either a temporally limited function associated with its signaling and regulatory roles, which is necessary for metabolic energy saving under stress conditions, or to possible relays of activation that appear to occur in a cascade as part of the complex gene regulatory network controlling the water-deficit stress response in plants (Shinozaki et al., 2017).

Interestingly, the ICS60 clone, which showed a higher RBOHF induction, also showed significantly higher induction of SOD at D23 than the TSH565 and EET8 clones. However, it should be noted that these clones also exhibited high induction of SOD. In any case, the coordinated induction of $R B O H F$ and $S O D$ suggests that a compensatory mechanism may be activated to counteract ROS accumulation in response to DS at least at the transcriptional level (Laxa et al., 2019), thus orchestrating gene induction by retrograde signaling as part of a systemic acquired acclimation response (Mittler and Blumwald, 2015) necessary for the tolerance and recovery of the evaluated cacao clones.

Concerning NTRC expression profiling, although downregulation was observed at D23 for the TSH565 clone, which is inconsistent with the induction observed for ICS60 and EET8, downregulation was the common pattern for all three clones at D26. NTRC appears to follow a similar expression pattern to $H S P$ and $R B O H F$ (i.e., induction followed by repression at the maximum level of stress), suggesting probable coregulation as part of the common gene regulatory network controlling this systemic response to DS. Indeed, thioredoxins (NTRCs) are disulfide reductases that regulate the redox state of other proteins and lipid peroxides. Therefore, their function has been related to the maintenance of metabolic pathways occurring in chloroplasts, such as photosynthesis, because of stress conditions (Vieira Dos Santos and Rey, 2006; Chaves et al., 2009). The NTRC protein family has been shown to protect chloroplasts from photooxidative damage generated by light stress and drought, both in rice (Perez-Ruiz, 2006) and Arabidopsis (Serrato et al., 2004; Toivola et al., 2013; Kim et al., 2017). Furthermore, there is evidence indicating that thioredoxins could act as regulators of ROS scavenging and as components of signaling pathways in the antioxidant system response of plants (Kim et al., 2017).

Similarly, UDPGT followed a similar profile, i.e., upregulated at D23 and downregulated at D26 in all clones. As UDPGT belongs to a family of enzymes responsible for glycosylation of regulators of plants, flavonoids, terpenoids and steroids (Sun et al., 2013), its activation is necessary to maintain the bioactivity of enzymatic cofactors and regulators of plants, including ABA, during stress conditions (Sun et al., 2013; Rehman et al., 2018). As reported by $\mathrm{Li}$ et al. (2017), the overexpression of UGT79B2/B3 increases anthocyanin accumulation, improving antioxidant activity under salinity stress, low temperatures and drought in Arabidopsis. In this study, we evaluated the ortholog in T. cacao of the A. thaliana AT4G34131.1 (UGT73B3) gene (Table 2). Rehman et al. (2018) proposed that this gene has a role in drought tolerance and oxidative stress response. Accordingly, the registered induction of UDPGT suggests that it could have 
similar functional roles, thus helping the plants address both kinds of stresses.

Ethanol synthesis and its accumulation have been reported as indicators of stress in plants, such as water deficit stress, thus affecting cellular energy via oxidative phosphorylation (Kelsey and Westlind, 2017). These results may occur due to aerobic respiration depletion, either by limiting the $\mathrm{O}_{2}$ supply or by mitochondrial damage (Manter and Kelsey, 2008; Schmidt et al., 2018). Under an adequate $\mathrm{O}_{2}$ supply, tissues metabolize pyruvate by oxidative phosphorylation, while with low $\mathrm{O}_{2}$ concentrations (hypoxia) or complete depletion (anoxia), the cytoplasmic $\mathrm{pH}$ drops, increasing the activity of the two fermentation enzymes (pyruvate decarboxylase $(P D C)$ and alcohol dehydrogenase $(A D H))$ responsible for ethanol accumulation in the cytoplasm of cells. This ethanol allows the regeneration of $\mathrm{NAD}^{+}$needed for glycolysis to continue producing the energy (ATP). In addition, it contributes to maintaining membrane integrity and its minimal functioning and stabilizing cellular $\mathrm{pH}$, thereby avoiding lethal acidosis until aerobic respiration resumes (Kelsey and Westlind, 2017). Here, $P D C, A D H$, and $L D H$ transcripts were evaluated to assess the other effects of the DS treatment on energy metabolism.

In this respect, the $L D H$ gene, which encodes a key enzyme involved in fermentative metabolism, was also upregulated at D23 and downregulated at D26 in the three clones. This pattern of expression suggests that the physiological stress caused by DS possibly triggered hypoxia in the cacao plants either by limiting oxygen supply or by accumulated damage in the mitochondria. Consequently, energy production by activation of fermentative metabolism may be part of the acclimation strategy upon DS in cacao. When hypoxia occurs, the predominant pathway is alcohol fermentation, where pyruvate is converted to acetaldehyde by pyruvate decarboxylase and then to ethanol by alcohol dehydrogenase (Dolferus et al., 2008). However, in addition to ethanol fermentation, plants also have a lactic acid fermentation pathway, where lactate dehydrogenase converts pyruvate to lactate. The relative activity of both fermentation pathways has often been correlated with tolerance to hypoxia or anoxia (Dolferus et al., 2008). Then, an increase in the levels of the $L D H$ transcript, recorded at $23 \mathrm{D}$, suggests that possibly the encoded protein accumulated in an early phase to attend to the hypoxic condition later.

Consistent with the above, the ICS60 and EET8 clones showed induction of the PDC gene at D23 and all clones showed upregulation of $A D H$ at both D23 and D26. Upregulation of the enzymes PDC and $\mathrm{ADH}$ is essential to maintain the generation of ATP, the energy piece required to keep the general metabolism functioning (Felle, 2005; Loreti et al., 2005). Although the LDH, $P D C$ and $A D H$ genes do not seem to follow a fully coordinated expression pattern between clones, it was evident as a general tendency that cacao may have switched its energetic metabolism from oxidative to fermentative as part of its acclimation response to DS, at least at the transcriptional level, which needs further experimental analysis at the protein expression and enzymatic activity level. Most of the leaves in all clones entered senescence at the maximum level of DS (D26) (visual evaluation), which could be a possible explanation for the general downregulation pattern observed at the transcriptional level for some of the fermentative metabolism genes, as well as all genes evaluated, and caused by a drastic change in energetic metabolism, with a probable trade-off between fermentative metabolism and maintenance respiration. However, transcriptional repression of a gene does not necessarily imply a drop in its respective protein level or activity, which could be maintained further. A similar behavior was described in conifers, which showed that all aerial tissues of drought-stressed seedlings accumulated ethanol when the tissues were near death or dying (Manter and Kelsey, 2008).

The expression patterns of fermentative genes observed here upon DS were not previously reported in cacao, although these gene patterns have been observed in A. thaliana, mainly in roots and stems (Dolferus et al., 2008; Mithran et al., 2014; Dumont et al., 2018). However, the induction of these genes was reported in cacao plants under waterlogging (Bertolde et al., 2014). These proteins and the different proteins associated with photosynthesis and oxidative stress were proposed as determining factors to distinguish between a tolerant genotype (TSH-792) to waterlogging and a susceptible genotype (TSH774) (Bertolde et al., 2014).

Most land plants experience mild flooding, but not all species have developed adaptations to grow and survive drastic changes in water availability in their environment (Jackson and Colmer, 2005; Jackson et al., 2009; Bailey-Serres et al., 2012; Herrera, 2013). It appears that T. cacao can induce the activation of fermentative pathways mediated by LDH, PDC, and $\mathrm{ADH}$ both in water excess and deficit, which in addition to being part of an acclimation response to probable stressinduced hypoxia may also constitute an adaptive plasticity trait to respond to different hydrological regimes naturally occurring in the Amazon rainforest, a seasonally flooded region that is also the central region of origin of Theobroma species (Motamayor et al., 2008; Cornejo et al., 2018). Altogether, these findings suggest the need for further integrated genetic, transcriptional, physiological, and biochemical characterizations of cacao germplasm for directing breeding to climate change adaptative traits. In particular, comparisons of these responses between its ten major genetic cluster will provide more insights into the different adaptative and acclimation counterparts of the cacao response and tolerance to DS.

\section{CONCLUDING REMARKS}

The results of the current study confirmed that the irrigation suspension period applied in the seven cacao clones led to severe drought stress. As an initial early response to DS, cacao plants exhibited regulation of stomatal closure (stomatal limitation) linked to the stress-avoidance mechanism; then, when DS became severe, a second phase response emerged with the downregulation of photosynthetic efficiency (nonstomatal limitation) as a consequence of oxidative stress and photoinhibition caused by DS. However, all plants recovered quickly (4 DAR), probably by mediating the antioxidant system as well as the efficiency of PSII repair mechanisms and the turnover of chloroplasts and their components, which represent crucial responses for maintaining photosynthesis and metabolism under stress conditions (Yang et al., 2019). Although all stressed cacao clones recovered, EET8 exhibited the highest 
tolerance, TSH565 exhibited a moderate response and ICS60 exhibited the highest susceptibility. Overall, the physiological response observed suggests that these cacao clones showed high phenotypic plasticity (De Almeida et al., 2019) and different levels of tolerance to drought (Tezara et al., 2020) that may allow them to respond to DS with diverse efficiency and varied responses at different levels. We report for the first time new insights into the cacao response to DS related to the participation of the antioxidant system and its probable role in physiological readjustment, protection, and energetic metabolism maintenance. These results are particularly important for seedling establishment in the field in which the frequency of irrigation can have an impact in production and yield due to the greater susceptibility of seedlings or young trees to dehydration (Almeida and Valle, 2007; Ayegboyin and Akinrinde, 2016; Medina and Laliberte, 2017). Furthermore, improving cacao to obtain varieties more tolerant to future climatic conditions caused by global warming is becoming more and more necessary, this requires research that integrates genetic, physiological, and multiple functional genomics approaches to elucidate the genetic and epigenetic bases of cacao DS responses and tolerance.

\section{DATA AVAILABILITY STATEMENT}

The raw data supporting the conclusions of this article will be made available by the authors, without undue reservation.

\section{AUTHOR CONTRIBUTIONS}

MO, LR, and WT conceived the project and experimental design. DC designed the gene expression profiling. MO and DC carried out the experiments, collected, analyzed data, and wrote the

\section{REFERENCES}

Acheampong, K., Hadley, P., and Daymond, A. J. (2013). Photosynthetic activity and early growth of four cacao genotypes as influenced by different shade regimes under West African dry and wet season conditions. Exp. Agric. 49, 31-42. doi: 10.1017/S0014479712001007

Ahuja, I., de Vos, R. C. H., Bones, A. M., and Hall, R. D. (2010). Plant molecular stress responses face climate change. Trends Plant Sci. 15, 664-674. doi: 10.1016/ j.tplants.2010.08.002

Akhtar, I., and Nazir, N. (2013). Effect of waterlogging and drought stress in plants. Int. J. Water Resour. Environ. Sci. 2, 34-40. doi: 10.5829/idosi.ijwres.2013.2.2. 11125

Alban, M., Apshara, S., Hebbar, K. B., Mathias, T., and Séverin, A. (2016). Morphophysiological criteria for assessment of two month old cocoa (Theobroma cacao L.) genotypes for drought tolerance. Indian J. Plant Physiol. 21, 23-30. doi: 10.1007/s40502-015-0195-y

Allen, R. G. (2006). Evapotranspiración Del Cultivo: Guias Para La Determinación De Los Requerimientos De Agua De Los Cultivos, Vol. 56. Rome: FAO.

Almeida, A.-A. F., Gomes, F. P., Araujo, R. P., Santos, R. C., and Valle, R. R. (2014). Leaf gas exchange in species of the Theobroma genus. Photosynthetica 52, 16-21. doi: 10.1007/s11099-013-0048-8

Almeida, A.-A., and Valle, R. R. (2007). Ecophysiology of the cacao tree. Brazilian J. Plant Physiol. 19, 425-448. doi: 10.1590/S1677-04202007000400011

Almeida, A.-A., Brito, R. C. T., Aguilar, M. A. G., and Valle, R. R. (2002). Water relations' aspect of Theobroma cacao L. clones. Agrotropica 14, 35-44. initial versions of the manuscript. All authors contributed to manuscript revision and improvement, read, and approved the submitted version.

\section{FUNDING}

This research was funded by the Vice-presidency for Research of the Pontificia Universidad Javeriana, under the following research grant: Project ID 7939 and ID 9823. MO was the recipient of the graduate student fellowship program "Formación de Capital Humano de Alto Nivel para el Departamento de Norte de Santander" ID 753 awarded by the Gobernación de Norte de Santander and MINCIENCIAS (Ministerio de Ciencia, Tecnología e innovación). DC was recipient of the Undergraduate student fellowship program "Ser Pilo Paga" of the Colombian Ministry of Education (year 2015).

\section{ACKNOWLEDGMENTS}

The authors thank Rafael Sierra and its company, Geoambiente SAS, for providing the plant material and facilitating the use of the glasshouse infrastructure. The authors also grateful for all the support from the technical staff of the "Bambusa" station, in particular that provided by Rodrigo Centeno and his family.

\section{SUPPLEMENTARY MATERIAL}

The Supplementary Material for this article can be found online at: https://www.frontiersin.org/articles/10.3389/fpls.2021. 700855/full\#supplementary-material

Altschul, S. F., Gish, W., Miller, W., Myers, E. W., and Lipman, D. J. (1990). Basic local alignment search tool. J. Mol. Biol. 215, 403-410. doi: 10.1016/S00222836(05)80360-2

Al-Whaibi, M. H. (2011). Plant heat-shock proteins: a mini review. J. King Saud. Univ. Sci. 23, 139-150. doi: 10.1016/j.jksus.2010.06.022

Antwi, A., Lopez, F., McDavid, C., and Spence, J. (1994). "Leaf morphology and drought tolerance in cocoa," in Proceedings of the 11th International Cocoa Research Conference 1993, Lagos.

Apshara, S. E., Rajesh, M. K., and Balasimha, D. (2013). Assessment of morphological, physiological and molecular characteristics of cocoa accessions from Central and South America in relation to drought tolerance. J. Plant. Crop. 41, 389-397.

Ara, N., Nakkanong, K., Lv, W., Yang, J., Hu, Z., and Zhang, M. (2013). Antioxidant enzymatic activities and gene expression associated with heat tolerance in the stems and roots of two cucurbit species ("Cucurbita maxima" and "Cucurbita moschata") and their interspecific inbred line "Maxchata.". Int. J. Mol. Sci. 14, 24008-24028. doi: 10.3390/ijms141224008

Araque, O., Jaimez, R. E., Tezara, W., Coronel, I., Urich, R., and Espinoza, W. (2012). Comparative photosynthesis, water relations, growth and survival rates in juvenile criollo cacao cultivars (Theobroma cacao) during dry and wet seasons. Exp. Agric. 48, 513-522. doi: 10.1017/S0014479712000427

Argout, X., Martin, G., Droc, G., Fouet, O., Labadie, K., Rivals, E., et al. (2017). The cacao Criollo genome v2.0: an improved version of the genome for genetic and functional genomic studies. BMC Genomics 18:730. doi: 10.1186/s12864-0174120-9 
Avila-Lovera, E., Coronel, I., Jaimez, R., Urich, R., Pereyra, G., Araque, O., et al. (2016). Ecophysiological traits of adult trees of Criollo cocoa cultivars (Theobroma cacao L.) from a germplasm bank in Venezuela. Exp. Agric. 52, 137-153. doi: 10.1017/S00144797140 00593

Ayegboyin, K. O. (2012). The Effect of Rootstock on the Genotypic Variability in Drought Tolerance of Theobroma cacao L. in Nigeria. doctoral dissertation. Reading: University of Reading.

Ayegboyin, K. O., and Akinrinde, E. A. (2016). Effect of Water Deficit Imposed during the Early Developmental Phase on Photosynthesis of Cocoa (Theobroma cacao L.). Agric. Sci. 7, 11-19. doi: 10.4236/as.2016.71002

Bailey-Serres, J., Lee, S. C., and Brinton, E. (2012). Waterproofing crops: effective flooding survival strategies. Plant Physiol. 160, 1698-1709. doi: 10.1104/pp.112. 208173

Bajji, M., Kinet, J. M., and Lutts, S. (2002). The use of the electrolyte leakage method for assessing cell membrane stability as a water stress tolerance test in durum wheat. Plant Growth Regul. 36, 61-70. doi: 10.1023/A:1014732714549

Baker, N. R. (2008). Chlorophyll fluorescence: a probe of photosynthesis in vivo. Annu. Rev. Plant Biol. 59, 89-113. doi: 10.1146/annurev.arplant.59.032607. 092759

Balasimha, D., Apshara, S. E., and Jose, C. T. (2013). Genotypic variations in chlorophyll fluorescence and stomatal conductance of cocoa in relation to drought tolerance. J. Plant Crop. 41, 40-45.

Balasimha, D., Daniel, E. V., and Bhat, P. G. (1991). Influence of environmental factors on photosynthesis in cocoa trees. Agric. For. Meteorol. 55, 15-21. doi: 10.1016/0168-1923(91)90019-M

Baligar, V. C., Bunce, J. A., Machado, R. C. R., and Elson, M. K. (2008), Photosynthetic photon flux density, carbon dioxide concentration, and vapor pressure deficit effects on photosynthesis in cacao seedlings. Photosynthetica 46, 216-221. doi: 10.1007/s11099-008-0035-7

Basu, S., Ramegowda, V., Kumar, A., and Pereira, A. (2016). Plant adaptation to drought stress [version 1; peer review: 3 approved]. F1000Research. 5:1554. doi: 10.12688/f1000research.7678.1

Bekele, F. L., Bekele, I., Butler, D. R., and Bidaisee, G. G. (2006). Patterns of morphological variation in a sample of cacao (Theobroma cacao L.) germplasm from the International Cocoa Genebank, Trinidad. Genet. Resour. Crop. Evol. 53, 933-948. doi: 10.1007/10722-004-6692-x

Bertolde, F. Z., Almeida, A.-A. F., and Pirovani, C. P. (2014). Analysis of gene expression and proteomic profiles of clonal genotypes from Theobroma cacao subjected to soil flooding. PLoS One 9:e108705. doi: 10.1371/journal.pone. 0108705

Bertolde, F. Z., Almeida, A.-A. F., Pirovani, C. P., Gomes, F. P., Ahnert, D., Baligar, V. C., et al. (2012). Physiological and biochemical responses of Theobroma cacao L. genotypes to flooding. Photosynthetica 50, 447-457. doi: 10.1007/ s11099-012-0052-4

Bhattacharjee, S., and Saha, A. K. (2014). "Plant water-stress response mechanisms," in Approaches to Plant Stress and their Management, eds P. Sharma and R. K. Gaur (New Delhi: Springer India), 149-172. doi: 10.1007/ 978-81-322-1620-9_8

Boza, E. J., Motamayor, J. C., Amores, F. M., Cedeno-Amador, S., Tondo, C. L., Livingstone, D. S., et al. (2014). Genetic characterization of the cacao cultivar CCN 51: its impact and significance on global cacao improvement and production. J. Am. Soc. Hortic. Sci. 139, 219-229.

Bray, E. A. (1997). Plant responses to water deficit. Trends Plant Sci. 2, 48-54. doi: 10.1016/S1360-1385(97)82562-9

Brodribb, T. (1996). Dynamics of changing intercellular CO2 concentration (ci) during drought and determination of minimum functional ci. Plant Physiol. 111, 179-185. doi: 10.1104/pp.111.1.179

Cardona, B. S. (2010). Acuerdo 003. Clones para Cacao en Colombia. in Chocoandino (Bogotá). Available online at: http: //huila.gov.co/documentos/agricultura/CADENASPRODUCTIVAS/ CLONESDECACAOPARACOLOMBIA.pdf (accessed February 19, 2017).

Carr, M. K. V., and Lockwood, G. (2011). The water relations and irrigation requeriments of cocoa (Theobroma cacao L.): a review. Exp. Agric. 47, 653-676. doi: $10.1017 / \mathrm{s} 0014479711000421$

Chang, S., Puryear, J., and Cairney, J. (1993). A simple and efficient method for isolating RNA from pine trees. Plant Mol. Biol. Rep. 11, 113-116. doi: 10.1007/ BF02670468
Chaouch, S., Queval, G., and Noctor, G. (2012). AtRbohF is a crucial modulator of defence-associated metabolism and a key actor in the interplay between intracellular oxidative stress and pathogenesis responses in Arabidopsis. Plant J. 69, 613-627. doi: 10.1111/j.1365-313X.2011.04816.x

Chaves, M. M., Flexas, J., and Pinheiro, C. (2009). Photosynthesis under drought and salt stress: regulation mechanisms from whole plant to cell. Ann. Bot. 103, 551-560. doi: 10.1093/aob/mcn 125

Chen, Z., Xu, J., Wang, F., Wang, L., and Xu, Z. (2019). Morpho-physiological and proteomic responses to water stress in two contrasting tobacco varieties. Sci. Rep. 9, 1-15. doi: 10.1038/s41598-019-54995-1

Cornejo, O. E., Yee, M.-C., Dominguez, V., Andrews, M., Sockell, A., Strandberg, E., et al. (2018). Population genomic analyses of the chocolate tree, Theobroma cacao L., provide insights into its domestication process. Commun. Biol. 1:167. doi: 10.1038/s42003-018-0168-6

Dai, A. (2011). Drought under global warming: a review. Wiley Interdiscip. Rev. Clim. Chang. 2, 45-65. doi: 10.1002/wcc.81

Damour, G., Vandame, M., and Urban, L. (2009). Long-term drought results in a reversible decline in photosynthetic capacity in mango leaves, not just a decrease in stomatal conductance. Tree Physiol. 29, 675-684. doi: 10.1093/ treephys/tpp011

Daymond, A. J., Tricker, P. J., and Hadley, P. (2011). Genotypic variation in photosynthesis in cacao is correlated with stomatal conductance and leaf nitrogen. Biol. Plant. 55, 99-104. doi: 10.1007/s10535-011-0013-y

De Almeida, J., Herrera, A., and Tezara, W. (2019). Phenotypic plasticity to photon flux density of physiological, anatomical and growth traits in a modern Criollo cocoa clone. Physiol. Plant. 166, 821-832. doi: 10.1111/ppl.12840

De Almeida, J., Tezara, W., and Herrera, A. (2016). Physiological responses to drought and experimental water deficit and waterlogging of four clones of cacao (Theobroma cacao L.) selected for cultivation in Venezuela. Agric. Water Manag. 171, 80-88. doi: 10.1016/j.agwat.2016.03.012

Demidchik, V. (2015). Mechanisms of oxidative stress in plants: From classical chemistry to cell biology. Environ. Exp. Bot. 109, 212-228. doi: 10.1016/j. envexpbot.2014.06.021

Ding, N., Wang, A., Zhang, X., Wu, Y., Wang, R., Cui, H., et al. (2017) Identification and analysis of glutathione S-transferase gene family in sweet potato reveal divergent GST-mediated networks in aboveground and underground tissues in response to abiotic stresses. BMC Plant Biol. 17:225. doi: 10.1186/s12870-017-1179-z

Dixon, D. P., and Edwards, R. (2005). Plant glutathione transferases. Methods Enzymol. 3, 1-10. doi: 10.1016/S0076-6879(05)01011-6

Dolferus, R., Wolansky, M., Carroll, R., Miyashita, Y., Ismond, K., and Good, A. (2008). Functional analysis of lactate dehydrogenase during hypoxic stress in Arabidopsis. Funct. Plant Biol. 35, 131. doi: 10.1071/fp07228

dos Santos, C. M., Verissimo, V., de Lins Wanderley Filho, H. C., Ferreira, V. M., da Silva, Cavalcante, P. G., et al. (2013). Seasonal variations of photosynthesis, gas exchange, quantum efficiency of photosystem II and biochemical responses of Jatropha curcas L. grown in semi-humid and semi-arid areas subject to water stress. Ind. Crops Prod. 41, 203-213. doi: 10.1016/j.indcrop.2012. 04.003

dos Santos, I. C., Almeida, A.-A., Anhert, D., da Conceicao, A. S., Pirovani, C. P., Pires, J. L., et al. (2014). Molecular, physiological and biochemical responses of Theobroma cacao L. genotypes to soil water deficit. PLoS One 9:e115746. doi: 10.1371/journal.pone.0115746

Dumont, S., Bykova, N. V., Khaou, A., Besserour, Y., Dorval, M., and Rivoal, J. (2018). Arabidopsis thaliana alcohol dehydrogenase is differently affected by several redox modifications. PLoS One 13:e0204530. doi: 10.1371/journal.pone. 0204530

Ezaki, B., Suzuki, M., Motoda, H., Kawamura, M., Nakashima, S., and Matsumoto H. (2004). Mechanism of gene expression of Arabidopsis glutathione S-transferase, AtGST1, and AtGST11 in Response to aluminum stress. Plant Physiol. 134, 1672-1682. doi: 10.1104/pp.103.037135.plants

FAO (2006). Evapotranspiracion Del Cultivo-Guías Para La Determinación De Los Requerimienbtos de Agua De Los Cultivos. Drain. Pap. FAO Irrig. Available online at: http://www.fao.org/3/x0490s/x0490s00.htm

Farnese, F. S., Menezes-Silva, P. E., Gusman, G. S., and Oliveira, J. A. (2016) When bad guys become good ones: the key role of reactive oxygen species and nitric oxide in the plant responses to abiotic stress. Front. Plant Sci. 7:471. doi: $10.3389 /$ fpls.2016.00471 
Farrell, A. D., Rhiney, K., Eitzinger, A., and Umaharan, P. (2018). Climate adaptation in a minor crop species: is the cocoa breeding network prepared for climate change? Agroecol. Sustain. Food Syst. 42, 812-833. doi: 10.1080/ 21683565.2018.1448924

Felle, H. H. (2005). pH regulation in anoxic plants. Ann. Bot. 96, 519-532. doi: 10.1093/aob/mci207

Foyer, C. H., and Shigeoka, S. (2011). Understanding oxidative stress and antioxidant functions to enhance photosynthesis. Plant Physiol. 155, 93-100. doi: $10.1104 /$ pp.110.166181

García Lozano, J. (2014). Caracterización De Las Respuestas Fisiológicas Y Bioquímicas En Tres Clones De Cacao (Theobroma cacao L.) Sometidos A Diferentes Niveles De Déficit Hídrico. Available online at: https://repositorio. unal.edu.co/handle/unal/52256 (accessed November 20, 2017).

García Lozano, J., and Moreno Fonseca, L. P. (2016). Respuestas fisiológicas de Theobroma cacao L. en etapa de vivero a la disponibilidad de agua en el suelo. Acta Agronómica 65, 44-50. doi: 10.15446/acag.v65n1.48161

Gateau-Rey, L., Tanner, E. V. J., Rapidel, B., Marelli, J.-P., and Royaert, S. (2018). Climate change could threaten cocoa production: effects of 2015-16 El Niñorelated drought on cocoa agroforests in Bahia. Brazil. PLoS One 13, e0200454. doi: 10.1371/journal.pone.0200454

Gilbert, M. E., and Medina, V. (2016). Drought adaptation mechanisms should guide experimental design. Trends Plant Sci. 21, 639-647. doi: 10.1016/j.tplants. 2016.03.003

González-González, M. F., Ocampo-Alvarez, H., Santacruz-Ruvalcaba, F., Sánchez-Hernández, C. V., Casarrubias-Castillo, K., Becerril-Espinosa, A., et al. (2020). Physiological, ecological, and biochemical implications in tomato plants of two plant biostimulants: arbuscular mycorrhizal fungi and seaweed extract. Front. Plant Sci. 11:999. doi: 10.3389/fpls.2020.00999

Griffiths, H., and Parry, M. A. J. (2002). Plant responses to water stress. Ann. Bot. 89, 801-802. doi: 10.1093/aob/mcf159

Gullner, G., Komives, T., Király, L., and Schröder, P. (2018). Glutathione S-transferase enzymes in plant-pathogen interactions. Front. Plant Sci. 9:1836. doi: 10.3389/fpls.2018.01836

Gupta, A., Rico-Medina, A., and Caño-Delgado, A. I. (2020). The physiology of plant responses to drought. Science 368, 266-269. doi: 10.1126/science.aaz7614

Hebbar, K. B., Apshara, E., Chandran, K. P., and Prasad, P. V. V. (2020). Effect of elevated $\mathrm{CO} 2$, high temperature, and water deficit on growth, photosynthesis, and whole plant water use efficiency of cocoa (Theobroma cacao L.). Int. J. Biometeorol. 64, 47-57. doi: 10.1007/s00484-019-01792-0

Herrera, A. (2013). Responses to flooding of plant water relations and leaf gas exchange in tropical tolerant trees of a black-water wetland. Front. Plant Sci. 4:106. doi: 10.3389/fpls.2013.00106

ICCO (2020). Quarterly Bulletin of Cocoa Statistics Cocoa year 2019/20, Vol. XLVI. London: ICCQ.

Ismail, M. R., Hassan, A. H., Dola, K., and Jalil, M. N. (1992). Growth, plant water relation and photosynthesis rate of young Theobroma cacao as influenced by water stress. Pertanika 15, 93-98.

Issa, A., Esmaeel, Q., Sanchez, L., Courteaux, B., Guise, J. F., Gibon, Y., et al. (2018). Impacts of paraburkholderia phytofirmans strain PsJN on tomato (lycopersicon esculentum L.) under high temperature. Front. Plant Sci. 871:1397. doi: 10.3389/ fpls.2018.01397

Jackson, M. B., and Colmer, T. D. (2005). Response and adaptation by plants to flooding stress. Ann. Bot. 96, 501-505. doi: 10.1093/aob/m ci205

Jackson, M. B., Ishizawa, K., and Ito, O. (2009). Evolution and mechanisms of plant tolerance to flooding stress. Ann. Bot. 103, 137-142. doi: 10.1093/aob/mcn242

Jiménez, S., Dridi, J., Gutiérrez, D., Moret, D., Irigoyen, J. J., Moreno, M. A., et al. (2013). Physiological, biochemical and molecular responses in four Prunus rootstocks submitted to drought stress. Tree Physiol. 33, 1061-1075. doi: 10. 1093/TREEPHYS/TPT074

Johnson, E. S., Bekele, F. L., Brown, S. J., Song, Q., Zhang, D., Meinhardt, L. W., et al. (2009). Population structure and genetic diversity of the Trinitario cacao (Theobroma cacao L.) from Trinidad and Tobago. Crop Sci. 49, 564-572. doi: 10.2135/cropsci2008.03.0128

Joly, R., and Hahn, D. (1989). Net CO2 assimilation of cacao seedlings during periods of plant water deficit. Photosynth. Res. 21, 151-159. doi: 10.1007/ BF00037179
Kapazoglou, A., Tani, E., Avramidou, E. V., Abraham, E. M., Gerakari, M., Megariti, S., et al. (2021). Epigenetic changes and transcriptional reprogramming upon woody plant grafting for crop sustainability in a changing environment. Front. Plant Sci. 11:2160. doi: 10.3389/fpls.2020.613004

Kelsey, R. G., and Westlind, D. J. (2017). Physiological stress and ethanol accumulation in tree stems and woody tissues at sublethal temperatures from fire. Bioscience 67, 443-451. doi: 10.1093/biosci/bix037

Kim, M. R., Khaleda, L., Jung, I. J., Kim, J. Y., Lee, S. Y., Cha, J.-Y., et al. (2017). Overexpression of chloroplast-localized NADPH-dependent thioredoxin reductase C (NTRC) enhances tolerance to photo-oxidative and drought stresses in Arabidopsis thaliana. J. Plant Biol. 60, 175-180. doi: 10.1007/ s12374-016-0464-y

Knopf, R. R., and Adam, Z. (2018). Lumenal exposed regions of the D1 protein of PSII are long enough to be degraded by the chloroplast Deg1 protease. Sci. Rep. 8, 5230. doi: 10.1038/s41598-018-23578-x

Köhler, M., Schwendenmann, L., and Hölscher, D. (2010). Throughfall reduction in a cacao agroforest: tree water use and soil water budgeting. Agric. For. Meteorol. 150, 1079-1089. doi: 10.1016/j.agrformet.2010.04.005

Kotak, S., Vierling, E., Baumlein, H., and Koskull-Doring, P. V. (2007). A novel transcriptional cascade regulating expression of heat stress proteins during seed development of Arabidopsis. Plant Cell Online 19, 182-195. doi: 10.1105/tpc. 106.048165

Kumar, N., and Jegadeeswari, V. (2019). Dynamics of gas exchange and chlorophyll fluorescence parameters of cocoa genotypes in response to water deficit. J. Pharmacogn. Phytochem. 8, 415-419.

Kwak, J. M. C., Mori, I., Pei, Z.-M., Leonhardt, N., Torres, M. A. L., Dangl, J., et al. (2006). NADPH oxidase AtrbohD and AtrbohF genes function in ROSdependent ABA signaling in Arabidopsis. EMBO J. 22, 2623-2633. doi: 10.1093/ emboj/cdg277

Läderach, P., Martinez-Valle, A., Schroth, G., and Castro, N. (2013). Predicting the future climatic suitability for cocoa farming of the world's leading producer countries, Ghana and Côte d'Ivoire. Clim. Change 119, 841-854. doi: 10.1007/ s10584-013-0774-8

Lahive, F., Hadley, P., and Daymond, A. (2019). The physiological responses of cacao to the environment and the implications for climate change resilience. a review. Agron. Sustain. Dev. 39:5. doi: 10.1007/s13593-018-0552-0

Laxa, M., Liebthal, M., Telman, W., Chibani, K., and Dietz, K. J. (2019). The role of the plant antioxidant system in drought tolerance. Antioxidants 8:94. doi: 10.3390/antiox8040094

Li, P., Li, Y. J., Zhang, F. J., Zhang, G. Z., Jiang, X. Y., Yu, H. M., et al. (2017). The Arabidopsis UDP-glycosyltransferases UGT79B2 and UGT79B3, contribute to cold, salt and drought stress tolerance via modulating anthocyanin accumulation. Plant J. 89, 85-103. doi: 10.1111/tpj.13324

Liu, B., Li, M., Cheng, L., Liang, D., Zou, Y., and Ma, F. (2012). Influence of rootstock on antioxidant system in leaves and roots of young apple trees in response to drought stress. Plant Growth Regul. 67, 247-256. doi: 10.1007/ s10725-012-9683-5

Loreti, E., Poggi, A., Novi, G., Alpi, A., and Perata, P. (2005). A genome-wide analysis of the effects of sucrose on gene expression in Arabidopsis seedlings under anoxia. Plant Physiol. 137, 1130-1138. doi: 10.1104/pp.104.057299

Manter, D. K., and Kelsey, R. G. (2008). Ethanol accumulation in drought-stressed conifer seedlings. Int. J. Plant Sci. 169, 361-369. doi: 10.1086/526462

Martínez-Ferri, E., Moreno-Ortega, G., Van Den Berg, N., and Pliego, C. (2019). Mild water stress-induced priming enhance tolerance to Rosellinia necatrix in susceptible avocado rootstocks. BMC Plant Biol. 19:458. doi: 10.1186/s12870019-2016-3

Medina, V., and Laliberte, B. (2017). A Review Of Research On The Effects Of Drought And Temperature Stress And Increased CO2 On Theobroma Cacao L., And The Role Of Genetic Diversity To Address Climate change. Costa Rica Bioversity Int. Available online at: https://cgspace.cgiar.org/handle/10568/89084 (accessed May 4, 2019)

Merilo, E., Yarmolinsky, D., Jalakas, P., Parik, H., Tulva, I., Rasulov, B., et al. (2018). Stomatal VPD response: there is more to the story than ABA. Plant Physiol. 176, 851-864. doi: 10.1104/pp.17.00912

Mishra, D., Shekhar, S., Singh, D., and Chakraborty, S. (2018). Regulation of Heat Shock Protein Responses. Cham: Springer International Publishing, 13. doi: 10.1007/978-3-319-74715-6 
Mithran, M., Paparelli, E., Novi, G., Perata, P., and Loreti, E. (2014). Analysis of the role of the pyruvate decarboxylase gene family in Arabidopsis thaliana under low-oxygen conditions. Plant Biol. 16, 28-34. doi: 10.1111/plb.12005

Mittler, R. (2002). Oxidative stress, antioxidants and stress tolerance. Trends Plant Sci. 7, 405-410. doi: 10.1016/S1360-1385(02)02312-9

Mittler, R., and Blumwald, E. (2015). The roles of ROS and ABA in systemic acquired acclimation. Plant Cell Online 27, 64-70. doi: 10.1105/tpc.114.133090

Morales, J., Kadota, Y., Zipfel, C., Molina, A., and Torres, M. A. (2016). The Arabidopsis NADPH oxidases RbohD and RbohF display differential expression patterns and contributions during plant immunity. J. Exp. Bot. 67, 1663-1676. doi: 10.1093/jxb/erv558

Mosa, K. A., Ismail, A., and Helmy, M. (2017). Plant Stress Tolerance. Cham: Springer, 273-280. doi: 10.1007/978-3-319-59379-1

Moser, G., Leuschner, C., Hertel, D., Hölscher, D., Köhler, M., Leitner, D., et al. (2010). Response of cocoa trees (Theobroma cacao) to a 13-month desiccation period in Sulawesi, Indonesia. Agrofor. Syst 79, 171-187.

Motamayor, J. C., Lachenaud, P., Silva, E., Mota, J. W., Loor, R., Kuhn, D. N., et al. (2008). Geographic and genetic population differentiation of the amazonian chocolate tree (Theobroma cacao L). PLoS One 3:e3311. doi: 10.1371/journal. pone.0003311

Nakashima, K., Yamaguchi-Shinozaki, K., and Shinozaki, K. (2014). The transcriptional regulatory network in the drought response and its crosstalk in abiotic stress responses including drought, cold, and heat. Front. Plant Sci. 5, 170. doi: 10.3389/fpls.2014.00170

Nishiyama, R., Watanabe, Y., Fujita, Y., Le, D. T., Kojima, M., Werner, T., et al. (2011). Analysis of cytokinin mutants and regulation of cytokinin metabolic genes reveals important regulatory roles of cytokinins in drought, salt and abscisic acid responses, and abscisic acid biosynthesis. Plant Cell 23, 2169-2183. doi: $10.1105 /$ tpc. 111.087395

Noctor, G. (2006). Metabolic signalling in defence and stress: the central roles of soluble redox couples. Plant Cell Environ. 29, 409-425. doi: 10.1111/j.13653040.2005.01476.x

Noctor, G., Mhamdi, A., and Foyer, C. H. (2016). Oxidative stress and antioxidative systems: Recipes for successful data collection and interpretation. Plant Cell Environ. 39, 1140-1160. doi: 10.1111/pce.12726

Noctor, G., Veljovic-Jovanovic, S., Driscoll, S., Novitskaya, L., and Foyer, C. H. (2002). Drought and oxidative load in the leaves of C3 plants: a predominant role for photorespiration? Ann. Bot. 89, 841-850. doi: 10.1093/aob/mc f096

Osakabe, Y., Osakabe, K., Shinozaki, K., and Tran, L.-S. P. (2014). Response of plants to water stress. Front. Plant Sci. 5:86. doi: $10.3389 /$ fpls.2014.0 0086

Osorio-Zambrano, M. A. (2021). Análisis Fisiológico Y Transcriptómico De La Respuesta A Déficit Hídrico En Cacao (Theobroma cacao L.) Para La Identificación De Genes Candidatos De Tolerancia A Estrés. doctoral dissertation. Bogotá, CO: Pontificia Universidad Javeriana.

Park, C. J., and Seo, Y. S. (2015). Heat shock proteins: a review of the molecular chaperones for plant immunity. Plant Pathol. J. 31, 323-333. doi: 10.5423/PPJ. RW.08.2015.0150

Parkash, V., and Singh, S. (2020). A review on potential plant-based water stress indicators for vegetable crops. Sustainability 12:3945. doi: 10.3390/su12103945

Pfaffl, M. W. (2001). A new mathematical model for relative quantification in real-time RT-PCR. Nucl. Acids Res. 29. doi: 10.1093/nar/29.9.e45

Perea Villamil, A., Martínez Guerrero, N., Aranzazu Hernández, F., and Cadena Cala, T. (2017). Caracteríscticas De Calidad Del Cacao De Colombia: Catálogo De 26 Cultivares. Bucaramanga: Universidad Industrial Santander.

Perez-Ruiz, J. M. (2006). Rice NTRC is a high-efficiency redox system for chloroplast protection against oxidative damage. Plant Cell Online 18, 23562368. doi: $10.1105 /$ tpc. 106.041541

Pfaffl, M. (2004). “Quantification strategies in real-timeRT-PCR," in The Real-time PCR Encyclopaedia A-Zof Quantitative PCR, 1st Edn, ed. S. A. Bustin (La Jolla, CA: International University Line), 87-112. doi: 10.1007/s10551-011-0963-1

Phillips-Mora, W., Aime, M. C., and Wilkinson, M. J. (2007). Biodiversity and biogeography of the cacao (Theobroma cacao) pathogen Moniliophthora roreri in tropical America. Plant Pathol. 56, 911-922. doi: 10.1111/j.1365-3059.2007. 01646.x

Pinheiro, T. T., Litholdo, C. G. Jr., Sereno, M. L., Leal, G. A. Jr., Albuquerque, P. S., and Figueira, A. (2011). Establishing references for gene expression analyses by RT-qPCR in Theobroma cacao tissues. Genet. Mol. Res. 10, 3291-3305. doi: 10.4238/2011.November.17.4

Prabhakaran Nair, K. P. (ed.). (2010). "5 - Cocoa (Theobroma cacao L.)," in The Agronomy and Economy of Important Tree Crops of the Developing World (London: Elsevier), 131-180. doi: 10.1016/B978-0-12-384677-8.00005-9

Qaderi, M., Martel, A., and Dixon, S. (2019). Environmental factors influence plant vascular system and water regulation. Plants 8:65. doi: 10.3390/plants8030065

R Core Team (2019). R: A Language And Environment For Statistical Computing. Available online at: http://www.r-project.org/ (accessed January 19, 2018).

Rada, F., Jaimez, R. E., García-Núñez, C., Azócar, A., and Ramírez, M. E. (2005). Relaciones hídricas e intercambio de gases en Theobroma cacao var. Guasare bajo períodos de déficit hídrico. Rev. Fac. Agron. 22, 112-120.

Ramalho, J. C., Rodrigues, A. P., Lidon, F. C., Marques, L. M. C., Leitão, A. E., Fortunato, A. S., et al. (2018). Stress cross-response of the antioxidative system promoted by superimposed drought and cold conditions in Coffea spp. PLoS One 13:e0198694. doi: 10.1371/journal.pone.0198694

Rehman, H. M., Nawaz, M. A., Shah, Z. H., Ludwig-Müller, J., Chung, G., Ahmad, M. Q., et al. (2018). Comparative genomic and transcriptomic analyses of Family-1 UDP glycosyltransferase in three Brassica species and Arabidopsis indicates stress-responsive regulation. Sci. Rep. 8, 1-18. doi: 10.1038/s41598018-19535-3

Ribeiro, M. A. Q., de Almeida, A. A. F., Alves, T. F. O., Gramacho, K. P., Pirovani, C. P., and Valle, R. R. (2016). Rootstock $\times$ scion interactions on Theobroma cacao resistance to witches' broom: photosynthetic, nutritional and antioxidant metabolism responses. Acta Physiol. Plant 38, 1-14. doi: 10.1007/s11738-0162095-9

Rodríguez, P. L., Nústez, L., Eduardo, C., Moreno, F., and Patricia, L. (2017). Drought stress affects physiological parameters but not tuber yield in three Andean potato (Solanum tuberosum L.) cultivars. Agron. Colomb. 35, 158-170.

Romero, J. A., Phillips-Mora, W., Arciniegas-Leal, A., Mata-Quirós, A., Haiminen, N., Mustiga, G., et al. (2017). Application of genome wide association and genomic prediction for improvement of cacao productivity and resistance to black and frosty pod diseases. Front. Plant Sci. 8:1905. doi: 10.3389/fpls.2017. 01905

Rozen, S., and Skaletsky, H. (2000). "Primer3 on the WWW for General Users and for Biologist Programmers," in Methods and protocols: methods in molecular biology, Vol. 132, eds S. Krawetz and S. Misener (Totowa, NJ: Humana Press), 365-386.

Saleh, L., and Plieth, C. (2009). Fingerprinting antioxidative activities in plants. Plant Methods 5:2. doi: 10.1186/1746-4811-5-2

Schmidt, R. R., Weits, D. A., Feulner, C. F. J., and Van Dongen, J. T. (2018). Oxygen sensing and integrative stress signaling in plants. Plant Physiol. 176, 1131-1142. doi: $10.1104 /$ pp.17.01394

Schroth, G., Läderach, P., Martinez-Valle, A. I., Bunn, C., and Jassogne, L. (2016). Vulnerability to climate change of cocoa in West Africa: Patterns, opportunities and limits to adaptation. Sci. Total Environ. 556, 231-241. doi: 10.1016/j. scitotenv.2016.03.024

Schwendenmann, L., Veldkamp, E., Moser, G., Hölscher, D., Köhler, M., Clough, Y., et al. (2010). Effects of an experimental drought on the functioning of a cacao agroforestry system, Sulawesi, Indonesia. Glob. Chang. Biol. 16, 1515-1530. doi: 10.1111/j.1365-2486.2009.02034.x

Serra, I., Strever, A., Myburgh, P. A., and Deloire, A. (2014). Review: the interaction between rootstocks and cultivars (Vitis vinifera L.) to enhance drought tolerance in grapevine. Aust. J. Grape Wine Res. 20, 1-14. doi: 10.1111/ajgw.12054

Serrato, A. J., Pérez-Ruiz, J. M., Spínola, M. C., and Cejudo, F. J. (2004). A novel $\mathrm{NADPH}$ thioredoxin reductase, localised in the chloroplast, which deficiency causes hypersensitivity to abiotic stress in Arabidopsis thaliana. J. Biol. Chem. 279, 43821-43827. doi: 10.1074/jbc.M404696200

Shao, H. B., Chu, L. Y., Shao, M. A., Jaleel, C. A., and Mi, H. M. (2008). Higher plant antioxidants and redox signaling under environmental stresses. Comptes Rendus Biol. 331, 433-441. doi: 10.1016/j.crvi.2008.03.011

Sharma, A., Kumar, V., Shahzad, B., Ramakrishnan, M., Singh Sidhu, G. P., Bali, A. S., et al. (2020). Photosynthetic response of plants under different abiotic stresses: a review. J. Plant Growth Regul. 39, 509-531. doi: 10.1007/s00344-01910018-x

Sharma, A., Shahzad, B., Kumar, V., Kohli, S. K., Sidhu, G. P. S., Bali, A. S., et al. (2019). Phytohormones Regulate accumulation of osmolytes under abiotic stress. Biomolecules 9:285. doi: 10.3390/biom9070285 
Sheoran, S., Thakur, V., Narwal, S., Turan, R., Mamrutha, H. M., Singh, V., et al. (2015). Differential activity and expression profile of antioxidant enzymes and physiological changes in wheat (Triticum aestivum L.) under drought. Appl. Biochem. Biotechnol. 177, 1282-1298. doi: 10.1007/s12010-015-1813-x

Shinozaki, K., Urano, K., Maruyama, K., and Takahashi, F. (2017). Drought stress A2 - thomas. Brian. Encycl. Appl. Plant Sci. 1, 8-15. doi: 10.1016/B978-0-12394807-6.00082-4

Slatyer, R. O., and Shmueli, E. (1967). "Measurements of internal water status and transpiration," in Irrigation of Agricultural Lands, eds R. M. Hagan, H. R. Haise, and T. W. Edminster (Hoboken, NJ: John Wiley \& Sons, Ltd), 337-353. doi: 10.2134/agronmonogr11.c19

Souza, V. L., Almeida, A.-A., Souza, J. D. S., Mangabeira, P. A. O., de Jesus, R. M., Pirovani, C. P., et al. (2014). Altered physiology, cell structure, and gene expression of Theobroma cacao seedlings subjected to Cu toxicity. Environ. Sci. Pollut. Res 21, 1217-1230. doi: 10.1007/s11356-013-1983-4

Stothard, P. (2000). The sequence manipulation suite: JavaScript programs for analyzing and formatting protein and DNA sequences. Biotechniques 28:1102. doi: 10.2144/00286ir01

Stuart, N. (1939). Comparative cold hardiness of scion roots from fifty apple varieties. Proc. Soc. Hort. Sci. 37:330.

Sun, Y., Wang, B., Jin, S., Qu, X., Li, Y., and Hou, B. (2013). Ectopic expression of arabidopsis glycosyltransferase UGT85A5 enhances salt stress tolerance in tobacco. PLoS One 8:e59924. doi: 10.1371/journal.pone.005 9924

Tardieu, F. (2013). Plant response to environmental conditions: assessing potential production, water demand, and negative effects of water deficit. Front. Physiol. 4:17. doi: $10.3389 /$ fphys.2013.00017

Tezara, W., Pereyra, G., Ávila-Lovera, E., and Herrera, A. (2020). Variability in physiological responses of Venezuelan cacao to drought. Exp. Agric. 56, 407-421. doi: 10.1017/S0014479720000058

Toivola, J., Nikkanen, L., Dahlström, K. M., Salminen, T. A., Lepistö, A., Vignols, H. F., et al. (2013). Overexpression of chloroplast NADPH-dependent thioredoxin reductase in Arabidopsis enhances leaf growth and elucidates in vivo function of reductase and thioredoxin domains. Front. Plant Sci. 4:389. doi: 10.3389/fpls.2013.00389

Tounekti, T., Mahdhi, M., Al-Turki, T. A., and Khemira, H. (2018). Water relations and photo-protection mechanisms during drought stress in four coffee (Coffea arabica) cultivars from southwestern Saudi Arabia. South African J. Bot. 117, 17-25. doi: 10.1016/j.sajb.2018.04.022

Valentovic, P., Luxova, M., Kolarovic, L., and Gasparikova, O. (2006). Effect of osmotic stress on compatible solutes content, membrane stability and water relations in two maize cultivars. Plant Soil Environ. 52:184. doi: 10.17221/3364PSE
Vieira Dos Santos, C., and Rey, P. (2006). Plant thioredoxins are key actors in the oxidative stress response. Trends Plant Sci. 11, 329-334. doi: 10.1016/j.tplants. 2006.05.005

Villar-Salvador, P., Planelles, R., Oliet, J., Peñuelas-Rubira, J. L., Jacobs, D. F., and González, M. (2004). Drought tolerance and transplanting performance of holm oak (Quercus ilex) seedlings after drought hardening in the nursery. Tree Physiol. 24, 1147-1155. doi: 10.1093/treephys/24.10. 1147

Voora, V., Bermúdez, S., and Larrea, C. (2019). Global Market Report: Cocoa. 13. Available online at: https://www.jstor.org/stable/pdf/resrep22025.pdf (accessed August 14, 2020).

Ward, N., and Moreno-Hagelsieb, G. (2014). Quickly finding orthologs as reciprocal best hits with BLAT, LAST, and UBLAST: how much do we miss? PLoS One 9:e101850. doi: 10.1371/journal.pone.010 1850

WCF (World Cocoa Foundation) (2014). Market Update, 11. Available online at: http://www.worldcocoafoundation.org/wp-content/uploads/ Cocoa-Market-Update-as-of-4-1-2014. (accessed April 1, 2014).

Yang, X., Li, Y., Qi, M., Liu, Y., and Li, T. (2019). Targeted control of chloroplast quality to improve plant acclimation: from protein import to degradation. Front. Plant Sci. 10:958. doi: 10.3389/fpls.2019.00958

Zuidema, P. A., Leffelaar, P. A., Gerritsma, W., Mommer, L., and Anten, N. P. R. (2005). A physiological production model for cocoa (Theobroma cacao): model presentation, validation and application. Agric. Syst. 84, 195-225. doi: 10.1016/ j.agsy.2004.06.015

Conflict of Interest: The authors declare that the research was conducted in the absence of any commercial or financial relationships that could be construed as a potential conflict of interest.

Publisher's Note: All claims expressed in this article are solely those of the authors and do not necessarily represent those of their affiliated organizations, or those of the publisher, the editors and the reviewers. Any product that may be evaluated in this article, or claim that may be made by its manufacturer, is not guaranteed or endorsed by the publisher.

Copyright (c) 2021 Osorio Zambrano, Castillo, Rodríguez Pérez and Terán. This is an open-access article distributed under the terms of the Creative Commons Attribution License (CC BY). The use, distribution or reproduction in other forums is permitted, provided the original author(s) and the copyright owner(s) are credited and that the original publication in this journal is cited, in accordance with accepted academic practice. No use, distribution or reproduction is permitted which does not comply with these terms. 